\title{
24. LIPID/BITUMEN MATURATION BY HYDROTHERMAL ACTIVITY IN SEDIMENTS OF MIDDLE VALLEY, LEG 1391
}

\author{
Bernd R.T. Simoneit ${ }^{2}$
}

\begin{abstract}
The accelerated diagenesis, maturation, and catagenesis of organic matter to hydrothermal petroleum was studied in sediments from Ocean Drilling Program Leg 139 in Middle Valley, northern Juan de Fuca Ridge. Sediments at Sites 855 and 856 have experienced high heat flow resulting in accelerated diagenesis of the immature organic matter without product migration. Fluid migration through these sediments has resulted in an influx of mature organic components, yielding diverse bitumen mixtures. At Site 857 the alteration has occurred in situ to the catagenetic stage and at Site 858, the hottest holes, the hydrothermal petroleums have migrated after generation. Maturation for the $n$-alkanes proceeds from high CPI values to $<1.0$ (i.e., strong even-carbon-number preference), and due to the low TOC these sediments do not generate high amounts of hydrocarbons from kerogen, thus revealing this unique carbon number preference. The biomarkers are converted from the biological precursors to the geological equivalents with various maturities. The organic matter is principally marine in origin and contains a significant terrigenous component, as confirmed by the alkane and biomarker distributions. High-temperature alteration yields polynuclear aromatic hydrocarbons, which in these sediments are concentrated in the high molecular weight range ( $>250$ dalton).
\end{abstract}

\section{INTRODUCTION}

Hydrothermal systems associated with oceanic spreading centers are now recognized as a common phenomenon, and the morphology, mineralogy, sedimentology, and fluid chemistry of the active systems in spreading centers has been reviewed (e.g., Barrett and Jambor, 1988; Rona, 1988; Rona et al., 1983; Simoneit, 1990a; Von Damm, 1990). The geochemistry of the alteration of sedimentary organic matter and associated fluid interactions have also been studied extensively (e.g., Bazylinski et al., 1988; Gieskes et al., 1988; Simoneit, 1985, 1990b; Simoneit et al., 1984, 1992; Welhan and Lupton, 1987; Whelan et al., 1988). Only one sedimented hydrothermal system, the Guaymas Basin, had been drilled before 1991 (Curray, Moore, et al., 1982). The purpose of this chapter is to provide an insight into the fate and chemical alterations of the organic matter, especially the biomarkers, under hydrothermal conditions in Middle Valley. The sedimentary organic matter in this system is influenced more by terrestrial influx than is the sedimentary organic matter in the Guaymas Basin (cf. Kvenvolden and Simoneit, 1990), and thus this study will be of interest in comparing the results with data from the other areas.

\section{Geological Setting}

Middle Valley is a northern segment of the Juan de Fuca Ridge, just south of the Sovanco fracture zone (Fig. 1A), and was the drilling area for the Ocean Drilling Program (ODP) Leg 139 (Shipboard Scientific Party, 1992; Davis, Mottl, Fisher, et al., 1992). It is a sedimented spreading center over zero-aged crust with limited discharge of hydrothermal fluids. Four sites were drilled in four distinct hydrologic environments (Fig. 1B) (Davis, Mottl, Fisher, et al., 1992) and are detailed below.

Middle Valley is a fault-bounded, "failed" spreading center with large-scale hydrothermal deposits. Abundant turbidite and hemipelagic sedimentation has filled the graben to depths of up to $1.5 \mathrm{~km}$ in the center, with as little as $100 \mathrm{~m}$ of sediments at the eastern edge, and hydrothermal mounds rise as topographic features above the valley floor

\footnotetext{
'Mottl, M.J., Davis, E.E., Fisher, A.T., and Slack, J.F. (Eds.), 1994. Proc. ODP, Sci Results, 139: College Station, TX (Ocean Drilling Program).

${ }^{2}$ Petroleum Research Group, College of Oceanic and Atmospheric Sciences, Oregon State University, Corvallis, OR 97331, U.S.A.
}

(Davis et al., 1987; Davis, Mottl, Fisher, et al., 1992). Efficient hydrothermal circulation maintains relatively uniform elevated temperatures in the upper igneous crust beneath a seal of low-permeability sediments (Davis and Villinger, 1992). The sediments at Sites 856,857, and 858 were influenced by hydrothermal activity.

\section{Site 855}

Site 855 is located across the hanging-wall block of the normal fault bounding the rift valley in the east (Fig. 1B). This is part of the recharge area for the valley. The sediment interstitial water has a composition similar to seawater, which supports fluid drawdown (Shipboard Scientific Party, 1992; Davis, Mottl, Fisher, et al., 1992). Heat flow is low, and therefore this site is chosen as the thermally least affected reference location (Davis, Mottl, Fisher, et al., 1992). The oldest sediment recovered in the four holes drilled is of Pleistocene age and the sediments consist of silty clay.

\section{Site 856}

Site 856 is situated in the eastern part of the valley on Bent Hill (diameter about $500 \mathrm{~m}$, elevation $60 \mathrm{~m}$ ), about $3 \mathrm{~km}$ west from the normal fault scarp with Site 855 (Fig. 1B). There is no present heatflow anomaly associated with Bent Hill (Davis and Villinger, 1992), but massive sulfide deposits just to the south were drilled. This site is interpreted to be a relict hydrothermal field that created the ore body (Shipboard Scientific Party, 1992; Davis, Mottl, Fisher, et al., 1992). The oldest sediment cored in the eight holes drilled is of Pleistocene age, and the Site 856 sequence consists of silty clay, silt, siltstone, and sulfidic breccia.

\section{Site 857}

Site 857 is located $5.2 \mathrm{~km}$ west from the normal fault scarp at Site 855 and $1.6 \mathrm{~km}$ south of the active hydrothermal system cored at Site 858 (Fig. 1B). A major thermal anomaly reaching $260^{\circ} \mathrm{C}$ was extrapolated at $476 \mathrm{~m}$ below seafloor ( $\mathrm{mbsf}$ ) and, because there is no active discharge, this site is considered to be the regional hydrothermal fluid reservoir (Davis and Wang, this volume; Shipboard Scientific Party, 1992; Davis, Mottl, Fisher, et al., 1992). Four holes were drilled and the oldest sediment is of Pleistocene age. The sedimentary sequence consists of silty clay, siltstone, claystone, and sulfidized matrix. 


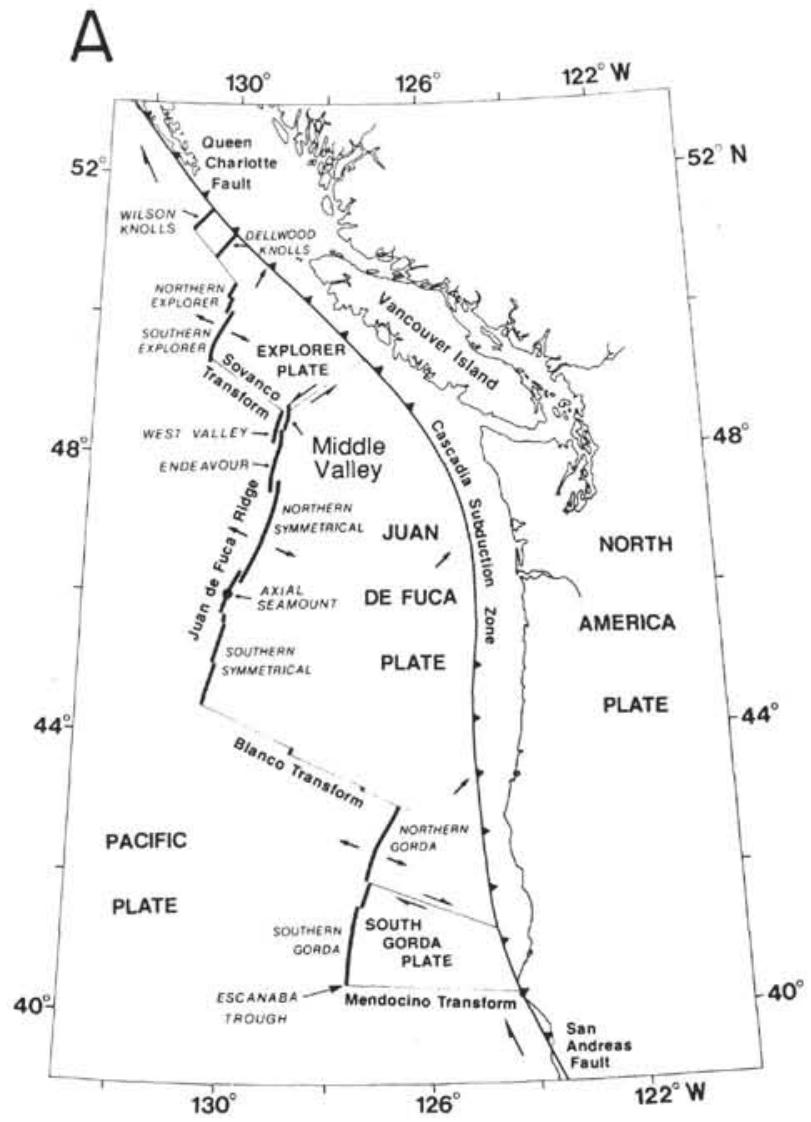

Figure 1. Location maps for the Middle Valley drilling area: (A) the northeastern Pacific rift systems and (B) ODP Leg 139 drill sites in Middle Valley.

\section{B}

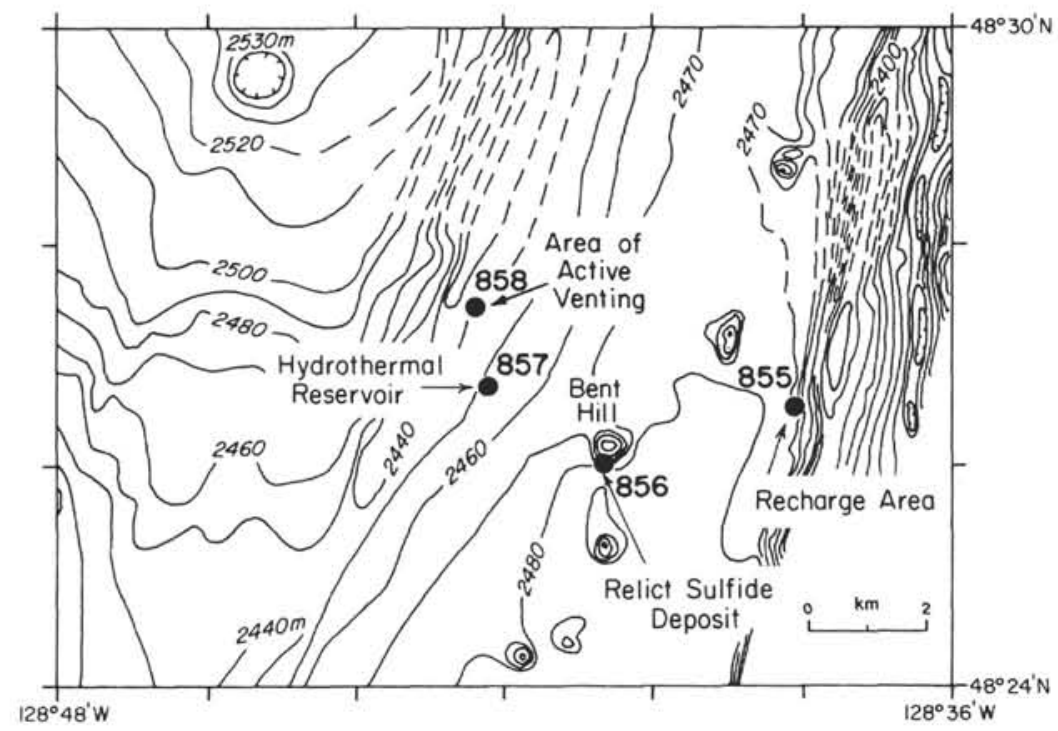

\section{Site 858}

Site 858 is located $1.6 \mathrm{~km}$ north of Site 857 in the same high thermal anomaly and in an active hydrothermal discharge area $(800 \times 400$ m) (Fig. 1B). The vent field is located over a local basement high with a sediment thickness ranging from 400 to $700 \mathrm{~m}$ (Shipboard Scientific Party, 1992; Davis, Mottl, Fisher, et al., 1992). Fluids discharge at temperatures of $255^{\circ}-265^{\circ} \mathrm{C}$ in most vents, and the conductive heat flow decreases systematically with distance from the field, falling to background levels within a few $100 \mathrm{~m}$ (Davis and Villinger, 1992). The results of previous piston coring and submersible sampling in this area have reported on the nature of the organic matter in those samples (Simoneit et al., 1992). The oldest sediment cored in the seven holes drilled is of Pleistocene age. Sediments from all holes are hydrothermally altered based on the occurrence of mineral assemblages, organic matter maturation (both diagenetic and thermal), bulk chemical 
composition, and physical properties (Davis, Mottl, Fisher, et al., 1992). The sedimentary sequence consists of claystone and siltstone, and their hydrothermally altered counterparts.

\section{EXPERIMENTAL METHODS}

Wet sediments $\left(3 \mathrm{~cm}^{3}\right.$ each) taken by minicore were extracted both aboard ship and in the laboratory with methanol and $n$-hexane $(1: 2,3$ $\mathrm{mL}$ each) by shaking, subsequent centrifugation $(2000 \mathrm{rpm})$, and removal of the hexane supernatant. The clear supernatant hexane extracts were pipetted into a second vial and evaporated under nitrogen blow-down at about $30^{\circ} \mathrm{C}$ to volumes ranging from 10 to $40 \mu \mathrm{L}$. Initial screening of sediment extracts was carried out aboard ship using the hexane supernatants from the extractions for fluorescence analyses $\left(3 \mathrm{~cm}^{3}\right.$ wet sediment each), which were removed and concentrated for analysis by the same method described (Davis, Mottl, Fisher, et al., 1992). Freeze-dried sediment samples $\left(3 \mathrm{~cm}^{3}\right.$ wet volume) were gently ground in an agate mortar and transferred into 1-dram screw-capped vials for similar extraction. Hexane $(2 \mathrm{~mL})$ and methanol $(0.5 \mathrm{~mL})$ were added, the suspension was heated at $60^{\circ} \mathrm{C}$ in a water bath and shaken occasionally for about $2 \mathrm{hr}$. After centrifugation a known volume of extract (usually $1 \mathrm{~mL}$ ) was transferred into a second vial and reduced in volume under nitrogen blow-down at about $30^{\circ} \mathrm{C}$ to volumes ranging from 10 to $40 \mu \mathrm{L}$. The extraction efficiency for all samples was corrected based on the volume transferred. The freeze-dried samples are marked in the data set (Table 1) to distinguish them from the wet-extracted sediments. Three samples were extracted both wet and dry and the extract yields were comparable (marked in Table 1).

A 1- to $3-\mu \mathrm{L}$ aliquot from a measured total volume was then injected onto the gas chromatograph (GC) or GC-mass spectrometer (MS) using normal protocol as detailed below. Compounds were identified by comparison of the retention times with those of authentic standards and confirmation by GC-MS. Response factors were determined for the various compound classes by GC and GC-MS analysis of representative standards, however, only hydrocarbons were quantitated in this study. (Note: The bitumen yield is based on the total GC signal due to resolved peaks and the unresolved complex mixture, or UCM, of branched cyclic hydrocarbons.) The final quantification of the results is based on the volume of wet sediment and the aliquot used in the injection. This type of quantitation allows the correlation of bitumen amount residing in a unit volume of sediment as it occurs in situ.

The shipboard GC is a Hewlett-Packard Model $5890 \mathrm{~A}$, fitted with a $30 \mathrm{~m} \times 0.25 \mathrm{~mm}$ capillary column coated with DB- $1(0.33 \mu \mathrm{m}$ film thickness). The temperature was programmed as isothermal for $3 \mathrm{~min}$ at $30^{\circ} \mathrm{C}, 10^{\circ} \mathrm{C} / \mathrm{min}$ to $220^{\circ} \mathrm{C}, 4^{\circ} \mathrm{C} / \mathrm{min}$ to $300^{\circ} \mathrm{C}$, and isothermal for $15 \mathrm{~min}$, with the injector at $250^{\circ} \mathrm{C}$, flame ionization detector (FID) at $300^{\circ} \mathrm{C}$, and helium as the carrier gas. The shore-based GC is also a Hewlett-Packard Model 5890A equipped with a $30 \mathrm{~m} \times 0.25 \mathrm{~mm}$ capillary column coated either with DB- $5(0.25 \mu \mathrm{m}$ film thickness $)$ or with DB-1 $(0.30 \mu \mathrm{m}$ film thickness). The GC oven temperature was programmed from $65^{\circ} \mathrm{C}$ (hold for $2 \mathrm{~min}$ ), to $310^{\circ} \mathrm{C}$ at $4^{\circ} \mathrm{C} / \mathrm{min}$, then isothermal for $30 \mathrm{~min}$, with the injector at $290^{\circ} \mathrm{C}$, FID at $325^{\circ} \mathrm{C}$, and $\mathrm{He}$ as the carrier gas.

Analyses by GC-MS were carried out with a Finnigan Model 9610 gas chromatograph coupled to a Finnigan Model 4021 quadrupole mass spectrometer operated at $70 \mathrm{eV}$ over the mass range $50-650$. The $\mathrm{GC}$ was fitted with an identical column to that described previously for the analytical GC, and the same temperature program and operating conditions were used. The GC-MS data were acquired and processed with an on-line Finnigan-Incos Model 2300 computer data system.

\section{RESULTS AND DISCUSSION}

The data are discussed in two parts. First, the general trends of the lipid/bitumen parameters are summarized for each site, and second, the precursor-product relationships and interconversions of the bio- marker compounds are presented. It should be emphasized that the lipid and biomarker data are presented as trends based on the alterations observed in conventional basin maturation (Hunt, 1979; Tissot and Welte, 1984) and not vs. sub-bottom depth for each hole. This is due to extensive lateral fluid invasion causing local organic matter alteration, thus resulting in complex sub-bottom trends. Some of the terms used in this text are defined in the Glossary at the end of this chapter.

\section{Lipid/Bitumen Data}

The discussion of the lipid results presents the initial data (Davis, Mottl, Fisher, et al., 1992) as updated by the additional shore-based analyses and recalculations. The revised data are listed in Table 1.

\section{Site 855}

The total organic carbon content ranges from $0 \%$ to $1.1 \%$, with a mean of $0.5 \%$ (Davis, Mottl, Fisher, et al., 1992), which is low compared to the $2 \%$ mean in the Guaymas Basin hydrothermal system (Curray, Moore, et al., 1982). The bitumen yields range from 0.6 to $23.4 \mu \mathrm{g} / \mathrm{cm}^{3}$ (Table 1), with an average of $7.1 \mu \mathrm{g} / \mathrm{cm}^{3}$, which can be taken as a reference value for relatively unaltered precursor (source) sediment. The dominant compound series in the total extracts are $n$-alkanes ranging from $\mathrm{C}_{15}$ to $\mathrm{C}_{35}$ with pristane $\left(\mathrm{C}_{19} \mathrm{H}_{40}, \mathrm{Pr}\right)$ as the major isoprenoid alkane (Table 1). A typical GC trace for an immature sample is shown in Figure 2A and others can be found in the organic geochemistry chapters of the shipboard report (Davis, Mottl, Fisher, et al., 1992). The $n$-alkanes $>C_{26}$ have a significant predominance of odd carbon numbers (e.g., Fig. 3A, carbon preference index, CPI, >1.0), typical for immature hydrocarbons that originate from terrestrial higher plants (Simoneit, 1977, 1978). The CPI for the range $\mathrm{C}_{26}-\mathrm{C}_{35}$ decreases vs. sub-bottom depth and increasing thermal alteration from 3.9 to 1.3 for Site 855 , where the latter value is for the strongly fluorescing bitumen in Core 139-855C-10R (Davis, Mottl, Fisher, et al., 1992). Maturation is also evident in the variable decreases of the isoprenoid to normal hydrocarbon ratios $\left(\mathrm{Pr} / n-\mathrm{C}_{17}=4.2\right.$ to $0.2, \mathrm{Ph} /$ $n-\mathrm{C}_{18}=1.3$ to 0.4$)$. The pristane to phytane $\left(\mathrm{C}_{20} \mathrm{H}_{42}\right)$ ratios $(\mathrm{Pr} / \mathrm{Ph})$ range from 5.0 to 0.8 , over depth intervals cored, possibly reflecting varying thermal stress. The $n$-alkane patterns $<\mathrm{C}_{24}$ with the unresolved complex mixture (UCM) of branched and cyclic compounds (e.g., Fig. $2 \mathrm{~A}$ ) are interpreted as typical for autochthonous marine bitumen derived from alteration of microbial detritus (Simoneit, 1977, 1978).

The hydrocarbon signature of these sediments represents an admixture of marine with lesser terrigenous components and is similar to those reported for shallow gravity cores taken near Site 858 at the Middle Valley hydrothermal vents (Simoneit et al., 1992). These hydrocarbon mixtures have matured significantly because of the high regional heat flow, which has accelerated diagenesis. At Site 855, the present bottom-water temperature is about $2^{\circ} \mathrm{C}$ and the sedimentary geothermal gradient is near $0.33^{\circ} \mathrm{C} / \mathrm{m}$, suggesting a maximum contemporary temperature of about $33^{\circ} \mathrm{C}$ in the deepest interval penetrated at about $100 \mathrm{mbsf}$. This temperature is too low to have produced any change in $\mathrm{Pr} / n-\mathrm{C}_{17}$ ratios with depth at Site 855 and suggests that the geothermal gradient was higher in the past. The strongly fluorescing bitumen in Core 139-855C-10R is also consistent with previous exposure of the deepest sediments at this site to temperatures high enough to take them into the beginning of the oil window $\left(>50^{\circ} \mathrm{C}\right.$ ) (Tissot and Welte, 1984; Hunt, 1979).

\section{Site 856}

The total organic carbon content varies from $0.1 \%$ to $0.9 \%$ with a mean of $0.34 \%$ (Davis, Mottl, Fisher, et al., 1992). The bitumen yields range from 0.4 to $5.6 \mu \mathrm{g} / \mathrm{cm}^{3}$ (Table 1), with an average of $1.9 \mu \mathrm{g} / \mathrm{cm}^{3}$ and significantly lower than the yields for Site 855 . No migrated bitumen is evident based on these yields. The dominant compound series in the total extracts is $n$-alkanes ranging from $\mathrm{C}_{15}$ to $\mathrm{C}_{35}$, with $\mathrm{Pr}$ and 

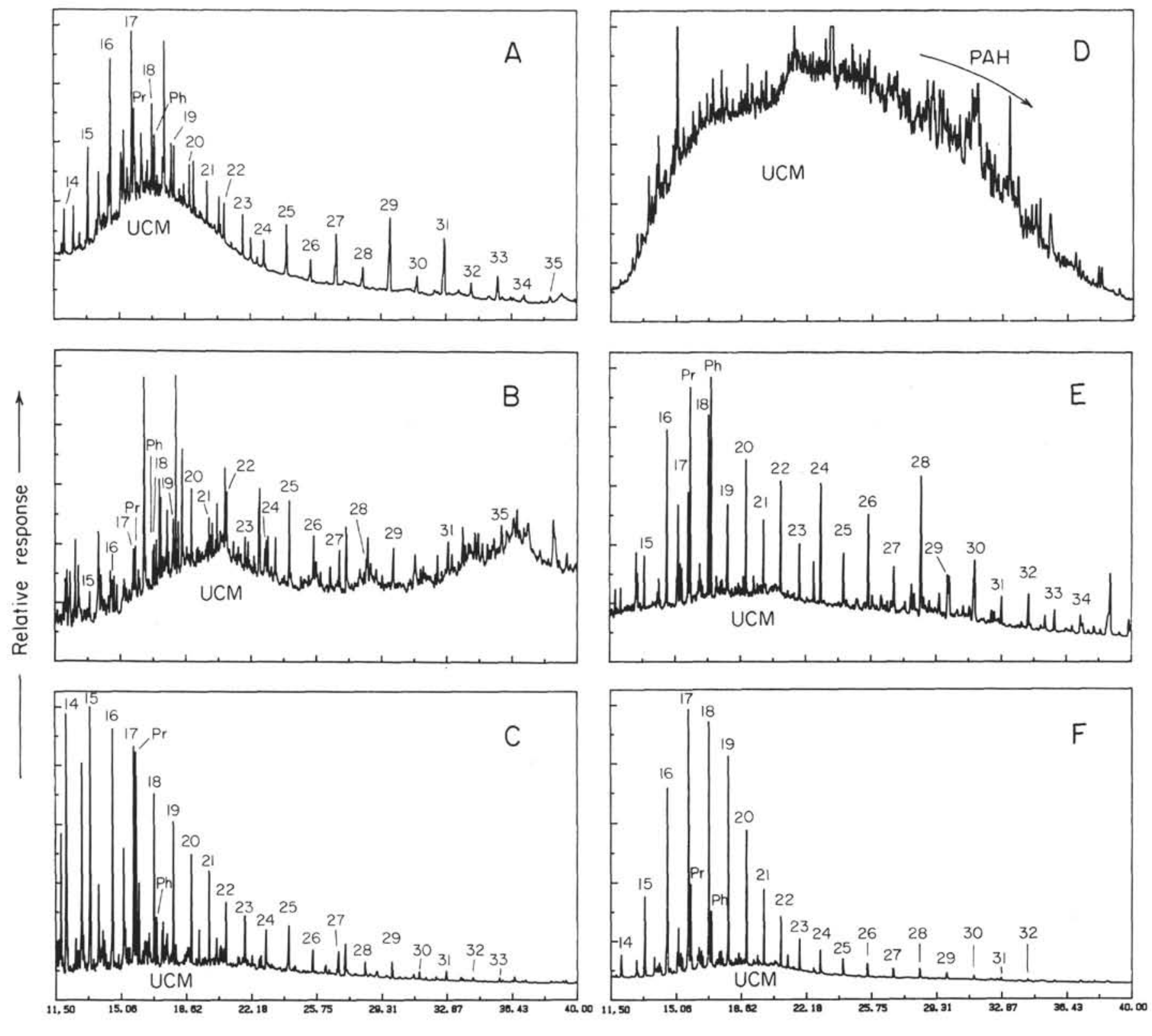

Figure 2. Gas chromatograms of total extracts of representative samples with immature lipids and hydrothermal petroleum or bitumen. A. Sample 139-855B-4R-3, 99-102 cm (immature). B. Sample 139-856A-1H-1, 0-1 cm (immature). C. Sample 139-858A-4H-4, 52-56 cm (mature). D. Sample 139-858A-6H-3, 137 cm (overmature). E. Sample 139-858C-2H-CC (mature). F. Sample 139-858D-4H-2, 133-135 cm (mature).

$\mathrm{Ph}$ as the major isoprenoid alkanes (Table 1). The $n$-alkanes $>\mathrm{C}_{26}$ have, for the most part, a significant predominance of odd carbon numbers $(\mathrm{CPI}>1.0)$ and carbon number maximum $\left(\mathrm{C}_{\max }\right)$ at $\mathrm{C}_{27}, \mathrm{C}_{29}$, or $\mathrm{C}_{31}$, typical for immature hydrocarbons with an origin from terrestrial higher plants (e.g., Figs. 2A, 2B, and 3B; Simoneit, 1977, 1978). The $n$-alkane patterns $<\mathrm{C}_{24}$ with the UCM of branched and cyclic compounds and the $\mathrm{C}_{\max }$ at $\mathrm{C}_{17}$ (e.g., Fig. 2A) are interpreted as typical for autochthonous marine bitumen derived from alteration of microbial detritus (Simoneit, 1977, 1978).

The CPI for Hole 856A decreases to less than 1 below $20 \mathrm{mbsf}$ (Davis, Mottl, Fisher, et al., 1992), indicative of an unusual hydrocarbon source with an even alkane predominance. Thermal maturation generally does not produce CPI values of less than 1 (Hunt, 1979; Tissot and Welte, 1984), so the decrease in CPI with depth in this hole must be at least partially source related.
Immature sediments usually exhibit $n$-alkane distributions with a strong odd-to-even carbon number predominance (CPI $>1.0)$ over the range from $C_{15}$ to $C_{35}$ and especially $>C_{23}$ (Simoneit, 1978). This is also observed for many shallow sediment samples from Leg 139 (e.g., Fig. $3)$. However, there are numerous reports of even-to-odd carbon number predominances $(\mathrm{CPI}<1.0)$ for $n$-alkanes over various ranges $\left(<\mathrm{C}_{20}\right.$ common, $>\mathrm{C}_{20}$ some, and full range rare) in a variety of sedimentary environments and some fossil-fuel samples (Welte and Ebhardt, 1968; Sever and Haug, 1971; Palacas et al., 1972; Welte and Waples, 1973; Albaiges and Torradas, 1974; Dastillung, 1976; Dembicki et al., 1976; Simoneit, 1975, 1977; Pelet and Debyser, 1977; Saliot and Tissier, 1978; Goutx and Saliot, 1980; Simoneit et al. 1980; Nishimura and Baker, 1986; Grimalt et al., 1986; Grimalt and Albaiges, 1987; Kennicutt and Brooks, 1990). In the case of the Leg 139 samples the $n$-alkane maturation proceeds from high CPI values to 1.0 and then for many 
Table 1. Various parameters for the solvent-soluble organic matter in sediments from Leg 139.

\begin{tabular}{|c|c|c|c|c|c|c|c|c|c|c|c|c|c|c|c|}
\hline $\begin{array}{l}\text { Core, section, } \\
\text { interval (cm) }\end{array}$ & $\begin{array}{l}\text { Depth } \\
\text { (mbsf) }\end{array}$ & $\begin{array}{c}\text { Yield } \\
\left(\mu \mathrm{g} / \mathrm{cm}^{3}\right)\end{array}$ & $\mathrm{C}_{\max } \mathrm{b} \quad \mathrm{C}$ & $\mathrm{CPI}_{(26-35)^{\mathrm{C}}}$ & $\mathrm{Pr} / \mathrm{Ph}$ & $\mathrm{Pr} / n-\mathrm{C}_{17}$ & $\mathrm{Ph} / n-\mathrm{C}_{18}$ & $\begin{array}{l}\text { Core, section, } \\
\text { interval }(\mathrm{cm})\end{array}$ & $\begin{array}{l}\text { Depth } \\
\text { (mbsf) }\end{array}$ & $\begin{array}{c}\text { Yield } \\
\left(\mu \mathrm{g} / \mathrm{cm}^{3}\right)\end{array}$ & $\mathrm{C}_{\max } \mathrm{b}$ & $\mathrm{CPI}_{(26-35)} \mathrm{c}$ & $\mathrm{Pr} / \mathrm{Ph}$ & $\mathrm{Pr} / n-\mathrm{C}_{17}$ & $\mathrm{Ph} / n-\mathrm{C}_{18}$ \\
\hline $139-855 \mathrm{~A}-$ & & & & & & & & $139-857 \mathrm{C}-$ & & & & & & & \\
\hline $1 \mathrm{R}-1,77-79$ & 0.78 & 11.60 & 17,29 & 3.0 & 1.1 & 0.4 & 0.7 & $2 \mathrm{R}-1,63-67$ & $57: 16$ & 7.40 & 17,18 & 22 & 13 & 0.5 & 0.8 \\
\hline $1 \mathrm{R}-3,114-116$ & 4.15 & 5.61 & 7,31 & 3.0 & 1.8 & 0.7 & 0.7 & $3 R-1,90-92$ & 67.41 & $\begin{array}{l}.40 \\
4.20\end{array}$ & $\begin{array}{l}17.29 \\
17.29\end{array}$ & 3.0 & 1.3 & 0.3 & 0.7 \\
\hline $2 \mathrm{R}-2,106-108$ & 10.17 & 4.20 & 17,29 & 2.4 & 2.3 & 0.4 & 0.5 & $3 R-3,38-40$ & 69.89 & 3.40 & 17,27 & 2.0 & 1.0 & 0.4 & 0.8 \\
\hline $3 \mathrm{R}-3,78-80$ & 20.39 & 3.00 & 17,27 & 1.9 & 2.5 & 0.5 & 0.4 & $5 \mathrm{R}-1,4-8$ & 82.16 & 23.20 & 17,27 & 2.1 & 1.3 & 0.4 & 1.2 \\
\hline $4 \mathrm{R}-3,31-33$ & 29.32 & 7.00 & 17.29 & 2.9 & 1.7 & 0.5 & 0.7 & $6 \mathrm{R}-1,66-68$ & 86.87 & 5.40 & 17,29 & 2.2 & 1.6 & 0.4 & 0.9 \\
\hline $5 \mathrm{R}-1,100-103$ & 36.52 & 8.01 & 7,29 & 1.7 & 1.2 & 0.4 & 0.4 & 6R-CC & $\begin{array}{l}80.01 \\
95.20\end{array}$ & 2.00 & 29,21 & 2.0 & 2.0 & 1.5 & 0.9 \\
\hline $6 \mathrm{R}-\mathrm{CC}$ & 55.10 & 5.20 & Pr, 27 & 3.2 & 5.0 & 4.2 & 1.3 & $8 \mathrm{R}-\mathrm{CC}$ & 114.50 & 4.00 & 20,25 & 1.5 & 1.0 & 0.6 & 0.4 \\
\hline $7 \mathrm{R}-3,43-46$ & 58.55 & 6.00 & 17,27 & 2.8 & 1.7 & 0.6 & 0.9 & 9R-CC & 124.10 & 6.20 & 29, $\mathrm{Pr}$ & 3.3 & 1.5 & 2.2 & 2.2 \\
\hline $130.855 \mathrm{~B}$ & & & & & & & & $10 \mathrm{R}-\mathrm{CC}$ & 133.80 & 3.60 & 20,29 & 2.4 & 1.2 & 0.8 & 0.7 \\
\hline 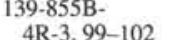 & & & & & & & & 11R-CC & 143.50 & 0.80 & 25,17 & 2.0 & 1.4 & 0.9 & 1.0 \\
\hline $\begin{array}{l}4 R-3,99-102 \\
6 R-1,25-29\end{array}$ & 28.51 & 3.40 & 17,29 & 2.6 & 1.6 & 0.5 & 0.6 & 12R-CC & 153.10 & 2.00 & $\operatorname{Pr}, 29$ & 2.0 & 2.2 & 3.3 & 1.3 \\
\hline $6 \mathrm{R}-1,25-29$ & 44.17 & 9.80 & 17,27 & 2.1 & 1.4 & 0.5 & 0.9 & $14 \mathrm{R}-3,0-3$ & 165.83 & 1.00 & Pr, 27 & 2.4 & 2.5 & 2.5 & 1.3 \\
\hline $139-855 \mathrm{C}-$ & & & & & & & & $21 \mathrm{R}-2,37-38$ & 232.48 & 2.80 & 16,28 & 0.9 & 1.7 & 0.8 & 0.7 \\
\hline $1 \mathrm{R}-1,66-69$ & 0.68 & 23.40 & 17.27 & 2.0 & 1.3 & 0.2 & 0.7 & $22 \mathrm{R}-1,124-127$ & 241.55 & 2.40 & 14,27 & 1.2 & 3.1 & 1.1 & 0.4 \\
\hline IR-5, 65-67 & 6.66 & 8.80 & 1731 & 2.0 & 11 & 0.2 & 0.8 & $28 \mathrm{R}-3,0-15$ & 296.87 & 0.80 & 17,18 & 1.5 & 1.5 & 0.2 & 0.3 \\
\hline $2 \mathrm{R}-4,67-71$ & $\begin{array}{r}0.00 \\
1380\end{array}$ & $\begin{array}{r}8.80 \\
98.00\end{array}$ & $\begin{array}{l}11,31 \\
17,29\end{array}$ & 2.1 & 0.8 & 0.4 & 0.8 & $31 \mathrm{R}-2,102-105$ & 325.24 & 1.80 & 18,28 & 0.9 & 2.4 & 0.9 & 0.3 \\
\hline $3 R-4,73-75$ & $\begin{array}{l}13.80 \\
22.90\end{array}$ & $\begin{array}{l}98.00 \\
47.00\end{array}$ & $\begin{array}{l}17,29 \\
17,29\end{array}$ & 2.2 & $\begin{array}{l}0.8 \\
1.4\end{array}$ & $\begin{array}{l}0.4 \\
0.6\end{array}$ & $\begin{array}{l}0.5 \\
0.5\end{array}$ & $40 \mathrm{R}-2,48-51$ & 367.40 & 0.60 & 17,28 & 0.9 & 0.6 & 0.2 & 0.6 \\
\hline $6 \mathrm{R}-\mathrm{CC}$ & 56.10 & 0.60 & 29,17 & 2.6 & 17 & $\begin{array}{l}0.0 \\
0.9\end{array}$ & 0.5 & $43 \mathrm{R}-1,66-70$ & 385.38 & 0.80 & Pr. 28 & 0.8 & 2.5 & 1.4 & 0.6 \\
\hline $7 R-4,69-73$ & 61.31 & 7.00 & 17.29 & 3.9 & 15 & 04 & 0.6 & $48 R-1,73-75$ & 409.44 & 1.20 & 17,30 & 0.8 & 1.2 & 0.5 & 0.6 \\
\hline 10R-3,0-5 & 87.93 & 7.20 & Pr. 29 & 1.9 & 34 & $\begin{array}{l}0.4 \\
3.3\end{array}$ & 0.6 & $51 \mathrm{R}-1,28-30$ & 423.69 & 0.80 & 17,27 & 1.1 & 0.6 & 0.2 & 0.8 \\
\hline $10 \mathrm{R}-4,78-82$ & 90.20 & $\begin{array}{l}.20 \\
6.20\end{array}$ & $\begin{array}{l}\text { Pr, } 29 \\
\text { Pr, } 29\end{array}$ & $\begin{array}{l}1.6 \\
2.2\end{array}$ & 2.0 & $\begin{array}{l}3.3 \\
3.3\end{array}$ & 1.12 & $53 \mathrm{R}-1,24-26$ & 433.05 & 0.60 & 27,17 & 1.0 & 1.6 & 0.6 & 0.7 \\
\hline 10R-CC & 94.60 & 2.40 & $\operatorname{Pr}, 31$ & 1.8 & 4.0 & 4.0 & 1.2 & $139.858 \mathrm{~A}$ & & & & & & & \\
\hline $11 \mathrm{R}-1,145-150$ & 96.08 & 1.20 & 17,29 & 1.6 & 1.8 & 0.9 & 1.2 & $\begin{array}{l}139-858 \mathrm{~A}- \\
1 \mathrm{H}-1,3-4\end{array}$ & 0.04 & 8.00 & 19,29 & 15 & 10 & 11 & 1.5 \\
\hline $139-855 \mathrm{D}$ & & & & & & & & 1H-1,5-7 & 0.06 & 118.00 & 17 & n.d. & 1.2 & $\begin{array}{l}1.1 \\
0.6\end{array}$ & 0.7 \\
\hline $\begin{array}{l}139-855 \mathrm{D}- \\
4 \mathrm{R}-1.0-5\end{array}$ & 10433 & & Pr 20 & & & & & $1 \mathrm{H}-1,52-53$ & 0.53 & 20.80 & 19.27 & 1.7 & 1.7 & 1.2 & 0.5 \\
\hline $\begin{array}{l}\text { 4R-1, , O-5 } \\
\text { 4R-C }\end{array}$ & 104.33 & 11.60 & $\mathrm{Pr}, 29$ & 1.3 & 4.5 & 4.0 & 1.1 & $\mathrm{IH}-1,57-58$ & 0.58 & 5.00 & 29. $\mathrm{Pr}$ & 2.8 & 1.8 & 1.2 & 0.6 \\
\hline & 108.50 & 8.03 & $1, \operatorname{Pr}$ & 2.6 & 2.5 & 1.8 & 0.7 & $1 \mathrm{H}-1,75-76$ & 0.76 & 6.80 & Pr, 29 & 1.5 & 3.2 & 2.0 & 0.6 \\
\hline $139-856 \mathrm{~A}-$ & & & & & & & & $1 \mathrm{H}-1,81-83$ & 0.82 & 5.80 & 29, $\mathrm{Pr}$ & 2.4 & 2.2 & 1.8 & 0.7 \\
\hline $1 \mathrm{H}-1,0-1$ & 0.00 & 4.42 & 0.29 & 1.2 & 1.3 & 10 & 10 & $1 \mathrm{H}-1,130-131$ & 1.31 & 6.00 & 29. $\mathrm{Pr}$ & 2.4 & 2.0 & 1.4 & 0.7 \\
\hline $1 \mathrm{H}-1,69-72$ & 0.70 & 3.60 & 17.29 & $\begin{array}{l}1.2 \\
3.1\end{array}$ & 1.1 & 0.5 & 0.8 & $1 \mathrm{H}-1,149-150$ & 1.50 & 100.80 & 25 & 0.7 & 0.7 & 0.3 & 0.3 \\
\hline $1 \mathrm{H}-2,35-37$ & 1.86 & 2.01 & 7,29 & 2.1 & 1.1 & 0.3 & $\begin{array}{l}0.8 \\
1.0\end{array}$ & $1 \mathrm{H}-2,12-14$ & 1.63 & 6.00 & $29, \mathrm{Pr}$ & 2.0 & 3.4 & 2.0 & 0.7 \\
\hline IH-CC & 2.70 & 1.42 & 7.20 & 1.8 & 1.1 & 0.6 & 0.5 & $2 \mathrm{H}-1,34-36$ & 2.75 & 1.80 & 29,20 & 2.1 & 1.4 & 0.6 & 0.5 \\
\hline $2 \mathrm{H}-1,61-64$ & 3.32 & 1.82 & 7,17 & 2.2 & 1.1 & 0.6 & 0.9 & $2 \mathrm{H}-2,85-87$ & 4.76 & 13.00 & 17,29 & 3.6 & 0.9 & 0.4 & 0.8 \\
\hline $2 \mathrm{H}-2,62-64$ & 4.83 & 2.61 & 7.29 & 0.9 & 1.0 & 0.0 & 0.9 & $2 \mathrm{H}-3,45-49$ & 5.87 & 2.40 & 29,20 & 1.8 & 1.7 & 0.8 & 0.6 \\
\hline $2 \mathrm{H}-3,83-85$ & $\begin{array}{l}.8 .83 \\
6.34\end{array}$ & $\begin{array}{l}2.01 \\
1.20\end{array}$ & 27.17 & 2.8 & 1.2 & $\begin{array}{l}0.1 \\
0.6\end{array}$ & 1.2 & $2 \mathrm{H}-5,28-32$ & 8.70 & 0.60 & $29, \mathrm{Pr}$ & 2.3 & 2.9 & 1.0 & 0.4 \\
\hline $2 \mathrm{H}-6,109-111$ & 11.30 & 0.61 & 7,27 & 1.1 & 1.3 & 0.8 & 1.6 & $2 \mathrm{H}-7,40-42$ & 11.80 & n.a. & 27 & 3.7 & 0.9 & 0.8 & 1.1 \\
\hline $2 \mathrm{H}-7,48-50$ & 12.19 & 1.00 & 17,29 & 3.4 & 1.7 & 0.8 & 1.1 & $2 \mathrm{H}-\mathrm{CC}$ & 11.90 & 2.20 & 29,20 & 1.7 & 0.7 & 0.5 & 0.5 \\
\hline $2 \mathrm{H}-\mathrm{CC}$ & 12.20 & 1.20 & 29.17 & 1.1 & 1.5 & 0.6 & 0.5 & $3 \mathrm{H}-3,81-85$ & 15.73 & 1.60 & 29,17 & 1.5 & 0.9 & 0.4 & 0.8 \\
\hline $3 \mathrm{H}-1,94-98$ & 13.16 & 0.60 & 17,27 & 3.1 & 1.2 & 0.9 & 0.3 & $3 \mathrm{H}-6,0-1$ & 19.41 & 2.00 & 29, $\mathrm{Pr}$ & 3.0 & 1.1 & 2.9 & 4.0 \\
\hline $3 \mathrm{H}-2,67-71$ & $\begin{array}{l}13.16 \\
14.39\end{array}$ & $\begin{array}{l}.60 \\
1.40\end{array}$ & $\begin{array}{l}17,27 \\
17,27\end{array}$ & $\begin{array}{l}3.1 \\
1.5\end{array}$ & $\begin{array}{l}1.2 \\
1.3\end{array}$ & $\begin{array}{l}0.9 \\
0.4\end{array}$ & $\begin{array}{l}0.3 \\
1.4\end{array}$ & $4 \mathrm{H}-2,0-1$ & 22.91 & 6.80 & 17,27 & 1.0 & 4.2 & 0.6 & 0.2 \\
\hline $3 \mathrm{H}-\mathrm{CC}$ & $\begin{array}{l}14.79 \\
21.70\end{array}$ & 0.42 & 7.17 & 1.0 & 0.8 & $\begin{array}{l}0.4 \\
0.2\end{array}$ & $\begin{array}{l}1.4 \\
0.5\end{array}$ & $4 H-4,52-56$ & 26.44 & 1.60 & 15,27 & 1.1 & 4.1 & 0.9 & 0.2 \\
\hline $4 \mathrm{H}-5,78-82$ & 28.50 & 4.61 & 7,28 & 0.7 & 1.1 & 0.3 & 10 & $5 \mathrm{H}-5,0-3$ & 36.92 & 0.60 & 17,27 & 1.0 & 1.0 & 0.3 & 0.5 \\
\hline $5 \mathrm{H}-2,63-67$ & 33.35 & 3.40 & 17,28 & 0.8 & 1.12 & 0.1 & 1.0 & $6 \mathrm{H}-3,55-56$ & 43.96 & 1.80 & 17,27 & 1.0 & 0.6 & 0.1 & 0.2 \\
\hline $5 \mathrm{H}-\mathrm{CC}$ & 40.70 & 2.40 & 29,20 & $\begin{array}{l}0.8 \\
3.6\end{array}$ & 1.2 & $\begin{array}{l}0.1 \\
0.5\end{array}$ & $\begin{array}{l}1.2 \\
0.4\end{array}$ & $6 \mathrm{H}-3,137$ & 44.77 & 76.00 & PAH & n.d. & n.d. & n.d. & n.d. \\
\hline $6 \mathrm{H}-4,49-53$ & 45.71 & 1.20 & 17,28 & 0.7 & 1.1 & $\begin{array}{l}0.1 \\
0.1\end{array}$ & $\begin{array}{l}0.4 \\
0.8\end{array}$ & $6 \mathrm{H}-\mathrm{CC}$ & 49.90 & 124.40 & $\mathrm{PAH}$ & n.d. & n.d. & n.d. & n.d. \\
\hline $7 \mathrm{H}-4,57-61$ & 55.29 & 0.60 & 17,28 & 0.7 & 1.3 & 0.4 & 1.3 & $7 \mathrm{H}-\mathrm{CC}$ & 58.90 & 0.40 & 17,27 & 1.5 & 0.2 & 0.1 & 0.8 \\
\hline & & & & & & & & $11 \mathrm{X}-\mathrm{CC}$ & 81.60 & 1.80 & 27.22 & 1.0 & 1.5 & 0.3 & 0.3 \\
\hline $\begin{array}{c}139-856 \mathrm{~B}- \\
\text { IH-CC }\end{array}$ & 180 & & 29. $\mathrm{Pr}$ & & & & & 139-858B= & & & & & & & \\
\hline $2 \mathrm{H}-6,123-127$ & $\begin{array}{l}1.80 \\
10.55\end{array}$ & $\begin{array}{l}\text { n.a. } \\
5.40\end{array}$ & $\begin{array}{l}29, \mathrm{PT} \\
17,27\end{array}$ & 0.9 & $\begin{array}{l}2.1 \\
0.8\end{array}$ & 0.2 & $\begin{array}{l}1.1 \\
0.7\end{array}$ & $\begin{array}{l}139-858 \mathrm{~B}- \\
1 \mathrm{H}-1,17-18\end{array}$ & 0.18 & 2.20 & $\operatorname{Pr}, 27$ & 1.2 & 2.5 & 2.0 & 0.6 \\
\hline $2 \mathrm{H}-\mathrm{CC}$ & 11.30 & 0.40 & 29,17 & 1.3 & 0.6 & 0.2 & $\begin{array}{l}0.7 \\
1.1\end{array}$ & $1 \mathrm{H}-1,48-52$ & 0.50 & 148.20 & 17.27 & 1.2 & 1.6 & 0.4 & 0.8 \\
\hline $3 \mathrm{H}-6,88-92$ & 19.70 & 0.60 & $17,18,25$ & 1.7 & 2.6 & 0.4 & 0.2 & $1 \mathrm{H}-1,54-55$ & 0.55 & 29.20 & Pr, 33 & 1.5 & 1.6 & 1.4 & 0.8 \\
\hline $4 \mathrm{H}-5,102-104$ & 27.83 & 1.00 & 17,28 & 0.7 & $\begin{array}{l}. .0 \\
0.8\end{array}$ & 0.1 & 0.2 & $1 \mathrm{H}-1,84-85$ & 0.85 & 4.60 & Pr, 27 & 1.0 & 1.7 & 1.1 & 0.7 \\
\hline $5 \mathrm{H}-4,34-39$ & 35.16 & 1.20 & 17,27 & 0.8 & 1.1 & 0.2 & 0.7 & $1 \mathrm{H}-1,124-125$ & 1.25 & 4.00 & 20,31 & 1.1 & 1.1 & 0.9 & 0.8 \\
\hline $7 \mathrm{H}-2,119-121$ & 52.00 & 5.60 & 17.27 & 1.1 & 1.2 & 0.4 & 0.9 & $1 \mathrm{H}-2,21-22$ & 1.72 & 4.20 & 17,27 & 1.1 & 1.2 & 0.5 & 0.7 \\
\hline 10-2, $119-121$ & 52.00 & 5.00 & 17,21 & 1.1 & 1.2 & 0.4 & 0.9 & $1 \mathrm{H}-2,31-32$ & 1.82 & 1.20 & 27, $\mathrm{Pr}$ & 0.9 & 1.4 & 1.1 & 1.4 \\
\hline $139-856 \mathrm{C}$ - & & & & & & & & $1 \mathrm{H}-2,41-42$ & 1.92 & 16.00 & 17,33 & 1.2 & 1.1 & 0.5 & 0.6 \\
\hline IH-CC & 2.00 & 0.60 & 29,21 & 1.2 & 0.9 & 1.6 & 1.6 & $1 \mathrm{H}-2,42-44$ & 1.93 & 21.00 & $17,20,27$ & 1.1 & 1.2 & 0.4 & 1.0 \\
\hline & & & & & & & & $1 \mathrm{H}-2,130-131$ & 2.81 & 11.20 & $\mathrm{Pr}, 31$ & 1.4 & 2.5 & 1.9 & 0.8 \\
\hline 139-856D- & & & & & & & & $1 \mathrm{H}-3,23-27$ & 3.25 & 5.20 & 17.29 & 2.4 & 1.3 & 0.4 & 0.9 \\
\hline $1 \mathrm{H}-\mathrm{CC}$ & 5.00 & 0.80 & 17,27 & 1.0 & 0.4 & 0.4 & 2.2 & $1 \mathrm{H}-3,34-35$ & 3.35 & $\begin{array}{r}5.20 \\
40.60\end{array}$ & 20, РAH & n.d. & 0.7 & 0.6 & 0.8 \\
\hline $139-856 \mathrm{E}$ - & & & & & & & & $1 \mathrm{H}-3,100-101$ & 4.01 & 17.20 & 20, PAH & n.d. & 1.4 & 1.4 & 0.8 \\
\hline 1 $\mathrm{H}-\mathrm{CC}-$ & 240 & 140 & 20.27 & 1 & 0.5 & 04 & 06 & $1 \mathrm{H}-4,19-2$ & 4.71 & 4.80 & 17,29 & 4.2 & 1.2 & 0.6 & 0.9 \\
\hline & 2.40 & 1.40 & 20,27 & 1.1 & 0.5 & 0.4 & 0.6 & $1 \mathrm{H}-4,38$ & 4.89 & 2.0 & 29,21 & 1.6 & 1.5 & 1.3 & 0.6 \\
\hline $139-857 \mathrm{~A}$ - & & & & & & & & $1 \mathrm{H}-4,42-43$ & 4.93 & 4.00 & Pr, 29 & 1.6 & 2.0 & 2.5 & 1.1 \\
\hline $1 \mathrm{H}-1,0-1$ & 1.90 & 4.40 & 27,21 & 2.6 & 0.5 & 0.9 & 0.7 & $1 \mathrm{H}-4,102-103$ & 5.53 & 2.8 & 29,18 & 1.4 & 1.6 & 1.7 & 0.5 \\
\hline $2 \mathrm{H}-2,73-75$ & 13.64 & 8.00 & 17,27 & 20 & 1.3 & 0.4 & & $1 \mathrm{H}$ & 6.61 & 3.6 & 22,27 & 0.9 & 1.1 & 0.4 & 0.3 \\
\hline $2 \mathrm{H}-\mathrm{CC}$ & 20.90 & 5.60 & 27,17 & 2.8 & 0. & 0 & 1 & 1H-CC, $0-1$ & 7.19 & 9.20 & Pr, 26 & 0.8 & 1.7 & 3.0 & 2.1 \\
\hline $3 \mathrm{H}-\mathrm{C}$ & 21.90 & 5. & 1 & 2. & 1. & 0. & 0 & 1H-CC, $14-15$ & 7.20 & 4.20 & Pr, 27 & 0.9 & 2.0 & 3.7 & 1.6 \\
\hline $4 \mathrm{H}-2,86-90$ & 24.28 & 11.60 & 1 & $\begin{array}{l}2.0 \\
4.1\end{array}$ & 1.5 & 0.4 & 0.9 & $2 \mathrm{H}$ & 16.70 & 7.40 & $17,20,27$ & 0.8 & 0.4 & 0.2 & 1.3 \\
\hline 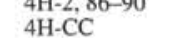 & $\begin{array}{l}24.28 \\
31.40\end{array}$ & $\begin{array}{r}11.60 \\
4.80\end{array}$ & $\begin{array}{l}17,27 \\
27,17\end{array}$ & $\begin{array}{l}4.1 \\
3.5\end{array}$ & $\begin{array}{l}1.5 \\
1.3\end{array}$ & $\begin{array}{l}0.4 \\
0.5\end{array}$ & $\begin{array}{l}0.9 \\
0.7\end{array}$ & $5 H-2,112-113$ & 26.53 & 1.00 & 20,29 & 0.9 & 0.3 & 0.2 & 0.6 \\
\hline $5 \mathrm{H}-\mathrm{CC}$ & 40.90 & 9.40 & 29,17 & 3.6 & 1.6 & 1.1 & 0.8 & & & & & & & & \\
\hline $6 \mathrm{H}-1,67-71$ & 41.60 & 3.80 & 17,29 & 2.7 & 1.7 & 0.6 & $\begin{array}{l}1.0 \\
1.0\end{array}$ & 139-858C- & & & & & & & \\
\hline $6 \mathrm{H}-4,54-58$ & 45.96 & 8.80 & 17,29 & 3.2 & 1.4 & 0.4 & 1.2 & $1 \mathrm{H}-1,22-26$ & 0.24 & 5.20 & Pr, 29 & 2.5 & 1.8 & 1.4 & 0.8 \\
\hline $7 \mathrm{H}-3$ & 54.23 & 6.20 & 17,27 & 2.6 & 1.8 & 0.4 & 0.5 & $1 \mathrm{H}-2,0-5$ & 1.53 & 9.40 & Pr, 29 & 2.4 & & 1.4 & 0.8 \\
\hline $8 \mathrm{H}-2,95-99$ & 62.37 & 5.00 & 17,29 & 2.4 & 1.9 & 0.9 & 1.0 & $1 \mathrm{H}-2,42-46$ & 1.94 & 4.00 & 17,29 & 3.1 & & 0.2 & 0.7 \\
\hline $9 \mathrm{H}-3,86-90$ & 73.28 & 9.00 & 17,27 & 2.2 & 1.2 & 0.3 & 0.7 & $1 \mathrm{H}-3,21-25$ & 3.23 & 7.60 & 17,29 & 4.0 & 1.0 & 0.2 & 1.2 \\
\hline $10 \mathrm{H}-2,79-81$ & 81.20 & 16.40 & 17.27 & 2.2 & 1.2 & 0.8 & 0 & & 3.93 & 21.40 & 17.29 & 3.0 & 1.1 & 0.3 & 0.6 \\
\hline $10 \mathrm{H}-6,26-28$ & $\begin{array}{l}01.20 \\
86.67\end{array}$ & $\begin{array}{r}10.4 \\
4.4\end{array}$ & 17,27 & 2.2 & 07 & 0.8 & 0.8 & $2 \mathrm{H}-2,77-79$ & 5.78 & 5. & 17 & 2. & 0 & 0.3 & 07 \\
\hline $10 \mathrm{H}-6,28-30$ & $\begin{array}{l}80.01 \\
86.67\end{array}$ & $\begin{array}{l}4.40 \\
260\end{array}$ & $\begin{array}{l}11,27 \\
17,27\end{array}$ & $\begin{array}{l}2.2 \\
2.4\end{array}$ & 0.1 & 0.3 & 0.5 & $2 \mathrm{H}-3,98-100$ & 7.49 & 58.60 & 17,29 & 2.7 & 1.4 & 0.5 & 0.8 \\
\hline $\begin{array}{l}10 \mathrm{H}-6,28-30 \\
33 \mathrm{X}-\mathrm{CC}\end{array}$ & 86.67 & $\begin{array}{r}2.60 \\
1460\end{array}$ & $\begin{array}{l}17,27 \\
18,27\end{array}$ & $\begin{array}{l}2.4 \\
1.1\end{array}$ & $\begin{array}{l}1.1 \\
1.3\end{array}$ & 0.3 & 0.6 & $2 \mathrm{H}-4,97-99$ & 8.96 & 5.60 & 17,29 & 3.1 & 1.1 & 0.8 & 1.1 \\
\hline & & & & & 1.3 & 1.2 & 0.5 & $2 \mathrm{H}-5,71-73^{\mathrm{d}}$ & 10.22 & 12.60 & 17,27 & 1.7 & 1.1 & 0.3 & 0.9 \\
\hline
\end{tabular}


Table 1 (continued).

\begin{tabular}{|c|c|c|c|c|c|c|c|}
\hline $\begin{array}{l}\text { Core, section, } \\
\text { interval }(\mathrm{cm})\end{array}$ & $\begin{array}{l}\text { Depth } \\
\text { (mbsf) }\end{array}$ & $\begin{array}{c}\text { Yield }^{3} \\
\left(\mu \mathrm{g} / \mathrm{cm}^{3}\right)\end{array}$ & $\mathrm{C}_{\max } \mathrm{b}$ & $\mathrm{CPI}_{(26-35)^{\mathrm{C}}}$ & $\mathrm{Pr} / \mathrm{Ph}$ & $\mathrm{Pr} / n-\mathrm{C}_{17}$ & $\mathrm{Ph} / n-\mathrm{C}_{18}$ \\
\hline $2 \mathrm{H}-6,12-14$ & 11.13 & 18.80 & 17,29 & 2.0 & 1.1 & 0.3 & 0.6 \\
\hline $2 \mathrm{H}-\mathrm{CC}$ & 13.00 & 114.40 & $\mathrm{Ph}, 28$ & 0.5 & 1.0 & 1.9 & 1.2 \\
\hline $3 \mathrm{H}-1,44-45$ & 13.45 & 528.80 & 17.28 & 0.7 & 0.2 & 0.2 & 2.2 \\
\hline $3 \mathrm{H}-1,90-91$ & 13.91 & 170.80 & 17.28 & 0.5 & 0.8 & 0.3 & 1.4 \\
\hline $3 \mathrm{H}-2,8-10$ & 14.59 & 118.60 & $\mathrm{Ph}, 26$ & 0.5 & 0.6 & 0.6 & 1.2 \\
\hline $3 \mathrm{H}-2,18-19$ & 14.69 & 145.40 & $\mathrm{Ph}, 28$ & 0.6 & 0.3 & 0.8 & 1.2 \\
\hline $3 \mathrm{H}-2,20-21$ & 14.71 & 98.80 & $\mathrm{Ph}, 28$ & 0.6 & 0.4 & 0.6 & 1.5 \\
\hline $3 \mathrm{H}-2,53-54$ & 15.04 & 169.60 & $\mathrm{Ph}, 28$ & 0.7 & 0.5 & 0.8 & 1.1 \\
\hline $3 \mathrm{H}-2,68-69$ & 15.19 & 70.60 & 17.28 & 0.7 & 0.5 & 0.4 & 1.4 \\
\hline $3 \mathrm{H}-2,108-109$ & 15.59 & 42.20 & 17.28 & 0.6 & 0.8 & 0.2 & 1.1 \\
\hline $3 \mathrm{H}-2,110-115^{\mathrm{d}}$ & 15.50 & 26.60 & 28 & 0.6 & 0.3 & 2.0 & 2.5 \\
\hline $3 \mathrm{H}-2,12 \mathrm{I}-122$ & 15.72 & 30.40 & 17.28 & 0.7 & 0.9 & 0.4 & 1.3 \\
\hline $3 \mathrm{H}-3,33-34$ & 16.34 & 41.40 & 17,30 & 0.9 & 1.0 & 0.6 & 1.0 \\
\hline $3 \mathrm{H}-4,120-121$ & 17.21 & 21.60 & 17,26 & 0.7 & 0.9 & 0.5 & 1.0 \\
\hline $3 \mathrm{H}-\mathrm{CC}$ & 22.50 & 3.00 & $\mathrm{Ph}, 27$ & 0.9 & 0.2 & 0.3 & 2.0 \\
\hline $5 \mathrm{H}-4,19-20$ & 28.20 & 24.00 & 17 & 1.1 & 1.3 & 0.4 & 0.8 \\
\hline $5 \mathrm{H}-5,63-64$ & 30.14 & 35.80 & 17 & 1.2 & 1.3 & 0.5 & 0.8 \\
\hline $5 \mathrm{H}-\mathrm{CC}$ & 33.00 & 1.40 & 26 & 0.9 & n.d. & n.d. & n.d. \\
\hline $7 \mathrm{H}-\mathrm{CC}$ & 46.50 & 4.20 & 20,26 & 0.9 & 0.7 & 0.4 & 0.4 \\
\hline $10 \mathrm{X}-\mathrm{CC}, 0-2$ & 54.50 & 8.60 & 20.26 & 1.0 & 0.8 & 0.5 & 0.4 \\
\hline $12 X-1,80-82$ & 64.81 & 1.80 & 17,28 & 0.6 & 0.8 & 0.5 & 0.9 \\
\hline \multicolumn{8}{|l|}{ 139-858D- } \\
\hline IH $-1,0-1$ & 0.00 & 1.40 & 29.17 & 1.6 & 2.6 & 1.0 & 0.4 \\
\hline $1 \mathrm{H}-1,67-70^{\circ}$ & 0.70 & 5.80 & 29. $\operatorname{Pr}$ & 1.7 & 1.4 & 1.4 & 0.8 \\
\hline $1 \mathrm{H}-1,145-150$ & 1.48 & 3.00 & 29, $\operatorname{Pr}$ & 2.5 & 2.9 & 1.7 & 0.6 \\
\hline $1 \mathrm{H}-2,19-21^{\mathrm{e}}$ & 1.70 & 4.60 & 29, $\operatorname{Pr}$ & 2.0 & 1.1 & 1.0 & 0.7 \\
\hline $1 \mathrm{H}-3,145-150$ & 4.48 & 5.60 & 29. $\operatorname{Pr}$ & 2.5 & 1.6 & 1.7 & 1.1 \\
\hline $\mathrm{IH}-4,146-150$ & 5.98 & 3.40 & 29,17 & 1.8 & 2.0 & 1.0 & 0.8 \\
\hline $1 \mathrm{H}-5,145-150$ & 7.48 & 3.80 & 29,17 & 2.1 & 2.0 & 0.7 & 0.7 \\
\hline $2 \mathrm{H}-3,145-150$ & 13.78 & 20.20 & Pr, 28 & 0.7 & 1.9 & 2.4 & 1.1 \\
\hline $2 \mathrm{H}-5,144-150$ & 16.78 & 8.80 & $\operatorname{Pr}, 28$ & 0.8 & 2.2 & 2.1 & 0.7 \\
\hline $2 \mathrm{H}-\mathrm{CC}, 37-40$ & 18.80 & 45.80 & 17 & 0.7 & 1.2 & 0.2 & 0.3 \\
\hline $3 \mathrm{P}-1,54-56$ & 19.35 & 166.40 & 18 & 0.9 & 1.9 & 0.3 & 0.2 \\
\hline $4 \mathrm{H}-2,133-135$ & 22.64 & 30.40 & 17 & 0.5 & 1.6 & 0.3 & 0.2 \\
\hline $4 \mathrm{H}-4,144-148^{\mathrm{e}}$ & 22.76 & 1.40 & 20.26 & 0.7 & 0.6 & 0.2 & 0.4 \\
\hline $4 \mathrm{H}-5,144-150$ & 27.28 & 5.60 & $24, \mathrm{Ph}$ & 0.9 & 0.3 & 0.4 & 1.4 \\
\hline $4 \mathrm{H}-6,100-103$ & 28.32 & 0.40 & $26(\mathrm{tr})$ & 0.7 & n.d. & n.d. & n.d. \\
\hline $6 \mathrm{X}-1,96-105$ & 29.81 & 3.60 & 26,17 & 0.8 & 0.4 & 0.2 & 0.7 \\
\hline
\end{tabular}

Notes: n.d. $=$ not detected, n.a. $=$ not analyzed, $\mathrm{tr}=$ trace, $\mathrm{Pr}=$ pristane, $\mathrm{Ph}=$ phytane, $\mathrm{PAH}$ = polynuclear aromatic hydrocarbons.

${ }^{\text {a }}$ Based on total GC signal integration of both resolved components and UCM, corrected for hydrocarbon response and aliquot fraction to the original wet sediment volume (using GC column with $0.33 \mu \mathrm{m}$ film thickness).

${ }^{\mathrm{b}}$ Major homologs are listed in decreasing order of intensity

${ }^{c}$ Carbon preference index calculated as simple ratio of $\frac{\left(C_{27}+C_{29}+C_{31}+C_{33}+C_{33}\right)}{\left(C_{20}+C_{28} C_{30}+C_{32}+C_{34}\right)}$.

${ }^{\mathrm{d}}$ Sample was freeze-dried prior to extraction.

${ }^{\mathrm{e}}$ Duplicate extraction (i.e., one wet and one freeze-dried).

hydrothermal petroleums $(-30 \%)$ to $<1.0$ (as low as 0.46 for a sample from Hole $858 \mathrm{C}$ ). This strong even-to-odd predominance was also observed over the full range from $n-\mathrm{C}_{14}$ to $n-\mathrm{C}_{34}$ for many samples (e.g., $858 \mathrm{C}-2 \mathrm{H}-\mathrm{CC}$ and $858 \mathrm{C}-3 \mathrm{H}-2,68-69 \mathrm{~cm}$, Fig. 2E).

The origins of the even $n$-alkanes have been discussed in the literature as (1) microbial alteration of algal detritus, (2) reductive processes acting on acids or other lipid compounds, and (3) direct microbial lipid input (e.g., Dembicki et al., 1976; Welte and Waples, 1973; Simoneit, 1977; Welte and Ebhardt, 1968; Grimalt et al., 1986; Nishimura and Baker, 1986). I propose that process number 2 occurs for these Leg 139 samples. Because maturation in these sediments begins with immature organic matter (i.e., biogenic detritus) that has not completed early diagenetic alteration, the $n$-alkanols from marine microbial sources and from terrestrial plant waxes (Simoneit, 1977, 1978) may be the source of the even-chain alkanes. This would require low-temperature alteration by dehydration and double-bond reduction of the $n$-alkanols (possibly $<100^{\circ} \mathrm{C}$ ) analogous to that described for the alteration of sedimentary organic matter in the Bransfield Strait by the intrusion of a volcanic plug (Brault and Simoneit, 1988). Further evidence in support of this proposal is as follows: (1) presence of $\mathrm{C}_{12}-\mathrm{C}_{20}$ alk-1-enes with a strong even-to-odd carbon number predominance near sills of Deep Sea Drilling Project (DSDP) Leg 64 Holes 478 and 481 (Simoneit et al., 1984), (2) unsaturated isoprenoid and steroid hydrocarbons in Bransfield Strait sediments

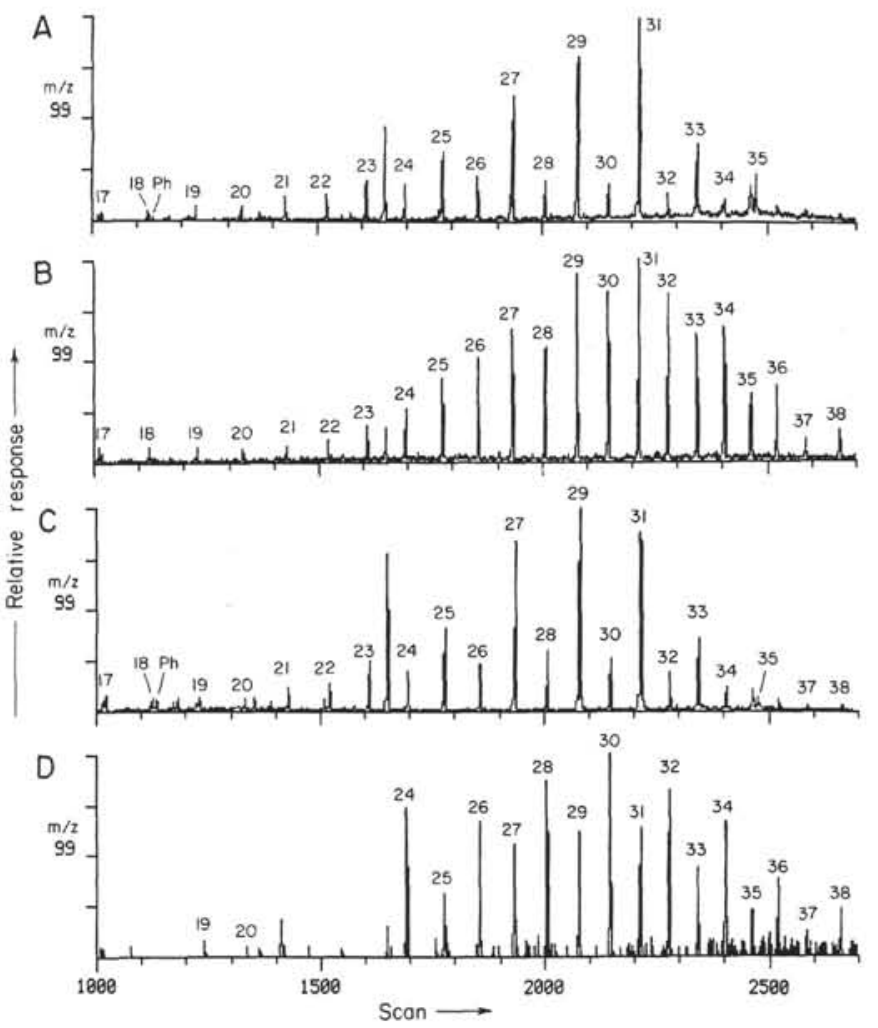

Figure 3. Mass fragmentograms of $\mathrm{m} / \mathrm{z} 99$ (a key ion for $n$-alkanes) for selected Leg 139 samples. A. Sample 139-855D-4R-CC. B. Sample 139-856A-2H-CC. C. Sample 139-857A-8H-2, 95-99 cm. D. Sample 139-857C-48R-1, 73-75 $\mathrm{cm}$. Numbers refer to the carbon chain length of the $n$-alkanes. $\mathrm{Ph}=$ phytane.

derived from thermally driven dehydration of the precursor alcohols (Brault and Simoneit, 1988), (3) rapid reduction (i.e., hydrogenation) of olefins and alcohols (probably via olefins) in hydrothermal laboratory simulations (Leif et al., 1991, 1992; Leif, 1993), and (4) high concentrations of $n$-alkanols and $n$-alkanals (both with strong even predominance) from plant wax in continental shelf sediments of this region (Prahl and Pinto, 1987). One anomalous higher CPI value of 3.6 occurs in Sample 139-856A-5H-CC at 40.7 mbsf within this even CPI trend (Davis, Mottl, Fisher, et al., 1992), which is possibly diagnostic of turbidites or different organic matter sources in some sections of this hole below 20 mbsf. This CPI value is the highest observed in this hole, equivalent to those observed at shallower depth. The slightly elevated $\mathrm{Pr} / n-\mathrm{C}_{17}$ and $\mathrm{Pr} / \mathrm{Ph}$ values and a somewhat lower $\mathrm{Ph} / n-\mathrm{C}_{18}$ values are also comparable between the shallow inter$\mathrm{val}$ and the $40.7 \mathrm{mbsf}$ sample.

CPI profiles for Holes $856 \mathrm{~B}, 856 \mathrm{C}, 856 \mathrm{D}$, and $856 \mathrm{E}$ have been reported (Davis, Mottl, Fisher, et al., 1992). The surficial CPI value of 3.2 in Hole $856 \mathrm{~B}$ at $1.8 \mathrm{mbsf}$ is in the same range as the highest values in the top 20 mbsf of Hole $856 \mathrm{~A}$. The CPI then decreases abruptly to values close to 1 in deeper sections of Hole $856 \mathrm{~B}$, suggestive of maturation. The samples with a CPI of $<1.0$ are diagnostic of a significant contribution from the even CPI source described previously for Hole 856A. CPI values for surficial samples from Holes $856 \mathrm{C}, 856 \mathrm{D}$, and $856 \mathrm{E}$ are all near 1.0 , consistent with those sediments experiencing higher thermal stress closer to the currently active hydrothermal vent area (Davis, Mottl, Fisher, et al., 1992).

Maturation is also evident by the decreases of the isoprenoid to normal hydrocarbon ratios $\left(\mathrm{Pr} / n-\mathrm{C}_{17}\right)$ from a maximum ranging from 0.75 to 1.5 in the shallow sections of Holes $856 \mathrm{~A}, 856 \mathrm{~B}$, and $856 \mathrm{C}$ to a minimum of 0.4 to 0.1 in deeper sections of Holes $856 \mathrm{~A}$ and $856 \mathrm{~B}$, as well as within the surficial sediments of Holes $856 \mathrm{D}$ and $856 \mathrm{E}$ (Davis, Mottl, Fisher, et al., 1992). These low $\mathrm{Pr} / n-\mathrm{C}_{17}$ values $(<0.5)$ 
are characteristic of sediments that, at some time in their history, were heated to temperatures greater than $50^{\circ} \mathrm{C}$, at the beginning of the oil thermal window (Farrington et al., 1988; Simoneit et al., 1981). The $\mathrm{Ph} / n-\mathrm{C}_{18}$ ratios do not show any systematic changes with depth or increasing geothermal gradients in these holes. These results are consistent with those observed elsewhere (Farrington et al., 1988; Simoneit et al., 1981).

$\mathrm{Pr} / \mathrm{Ph}$, which has been reported to be influenced both by source (e.g., Didyk et al., 1978) and by maturation (e.g., Simoneit et al., 1981), generally shows low and fluctuating values in the range of 0.8 to 1.5 in the 10 to $60 \mathrm{mbsf}$ section of Hole $856 \mathrm{~A}$, as well as in most sections of Holes $856 \mathrm{~B}, 856 \mathrm{C}, 856 \mathrm{D}$, and $856 \mathrm{E}$ (overall range 0.4 to 2.6; Davis, Mottl, Fisher, et al., 1992). $\mathrm{Pr} / \mathrm{Ph}$ values in some of the samples from less than 20 mbsf in Hole $856 \mathrm{~A}$ are $>1.5$. It is possible that the variation and decrease in general with increasing depth and thermal stress are indicative of maturation effects.

The overall hydrocarbon signatures of the surficial intervals of the Site 856 sediments are also similar to those reported for shallow gravity cores taken near Site 858 at the Middle Valley hydrothermal vents (Simoneit et al., 1992). In the deeper intervals, however, the bitumens do not resemble other mature hydrothermal petroleums found in Escanaba Trough (Kvenvolden et al., 1986) or Guaymas Basin (Simoneit, 1985; Kawka and Simoneit, 1987).

\section{Site 857}

The total organic carbon (TOC) content varies from $0 \%$ to $0.8 \%$, with a mean of $0.36 \%$ (Fig. 4A; Davis, Mottl, Fisher, et al., 1992), which is low compared to the Guaymas Basin hydrothermal system (Curray, Moore, et al., 1982). The bitumen yields for Site 857 range from 0.6 to $23.2 \mu \mathrm{g} / \mathrm{cm}^{3}$ (Table 1), with an average of $5.3 \mu \mathrm{g} / \mathrm{cm}^{3}$. These yields are similar to those for Sites 855 and 856 and are low compared to Site 858 . Hole $857 \mathrm{C}$ shows a trend of gradually decreasing bitumen amounts vs. sub-bottom depth (Table 1). The low yields together with low TOC values (Davis, Mottl, Fisher, et al., 1992) indicate that migrated bitumens are probably not important and that the hydrocarbon signatures can be utilized as indicators for in-situ alteration conditions. The gradual concentration decrease vs. depth may indicate thermal alteration (oxidation) of the organic matter, possibly to $\mathrm{CO}_{2}$.

The dominant compound series in the total extracts is hydrocarbons ranging from $n-\mathrm{C}_{14}$ to $n-\mathrm{C}_{35}$, with pristane and phytane as the major isoprenoid alkanes (Fig. $3 \mathrm{C}$ ). The $n$-alkanes $>\mathrm{C}_{26}$ have a significant predominance of odd carbon numbers $(\mathrm{CPI}>1.0)$ and $\mathrm{C}_{\max }$ at $\mathrm{C}_{27}$ or $\mathrm{C}_{29}$ in the upper sections of Holes $857 \mathrm{~A}$ and $857 \mathrm{C}$, which is typical for immature hydrocarbons with an origin from terrestrial higher plants (Simoneit, 1977, 1978). The $n$-alkane patterns $<\mathrm{C}_{24}$ with the UCM of branched and cyclic compounds and the $\mathrm{C}_{\max }$ at $\mathrm{C}_{17}$ are interpreted as typical for autochthonous marine bitumen derived from alteration of microbial lipids (Davis, Mottl, Fisher, et al., 1992).

The CPI for Hole 857A decreases gradually from 4 to 2 and then drops to 1 below 100 mbsf (Davis, Mottl, Fisher, et al., 1992), indicative of enhanced diagenesis/maturation resulting from high regional heat flow. The CPI profile for Hole $857 \mathrm{C}$ also decreases to values of 1 and $<1$ below $200 \mathrm{mbsf}$, consistent with increasing thermal stress vs. depth together with a source of the even-predominance alkanes. The variability of the surficial CPI values in both holes reflects different source inputs of marine and terrestrial organic matter. The CPI $<1$, that is, even-carbon-number predominance of $n$-alkanes, in the lower sections of Hole $857 \mathrm{C}$ (e.g., Fig. 3D) is comparable to distributions described for Site 856, DSDP sediments from Legs 5 and 18 in the northeastern Pacific to the south of this region (Simoneit, 1977), and other geographic areas (e.g., Grimalt and Albaiges, 1987). As discussed earlier, this decrease in CPI with depth in this hole may be partially source related and is a consequence of maturation.

Maturation was not evident in $\mathrm{Pr} / n-\mathrm{C}_{17}$ and $\mathrm{Ph} / n-\mathrm{C}_{18}$ ratios for Hole $857 \mathrm{~A}$ and only a slight trend was observed below $170 \mathrm{mbsf}$ for Hole 857C (Davis, Mottl, Fisher, et al., 1992). Low $\mathrm{Pr} / n-\mathrm{C}_{17}$ and
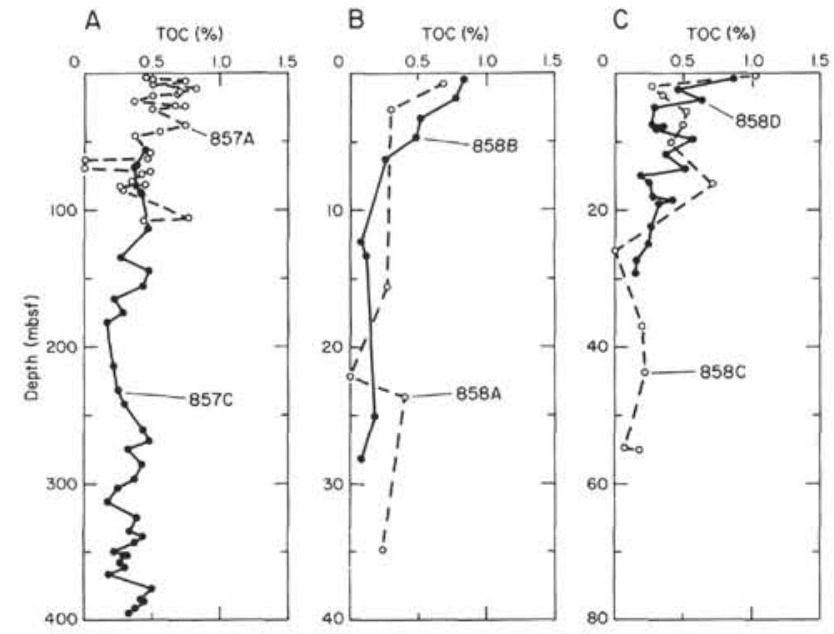

Figure 4. Plots of total organic carbon (\%) vs. sub-bottom depth for Holes 857 A and $857 \mathrm{C}(\mathbf{A})$, Holes $858 \mathrm{~A}$ and $858 \mathrm{~B}(\mathbf{B})$, and Holes $858 \mathrm{C}$ and $858 \mathrm{D}(\mathbf{C})$ (replotted from data by Davis, Mottl, Fisher, et al., 1992).

$\mathrm{Ph} / n-\mathrm{C}_{18}$ values $(<0.5)$ are characteristic of sediments in conventional basins that have been heated to the beginning of the oil thermal window (Hunt, 1979). $\mathrm{Pr} / \mathrm{Ph}$, which has been reported to be influenced both by source and by maturation, generally shows fluctuating values in the range of 0.5 to 3.1 for both holes, which may reflect the organic matter sources rather than maturation (Davis, Mottl, Fisher, et al., 1992).

\section{Site 858}

The TOC values vary from $0 \%$ to $1.0 \%$, with a mean of $0.32 \%$ and generally elevated values in the upper 5-10 mbsf (Figs. 4B and 4C; Davis, Mottl, Fisher, et al., 1992). The bitumen yields for Site 858 range from 0.4 to $528.8 \mu \mathrm{g} / \mathrm{cm}^{3}$ (Table 1), with an average of 32.3 $\mu \mathrm{g} / \mathrm{cm}^{3}$. The yields are high within discrete intervals in the upper sections of Holes $858 \mathrm{~A}, 858 \mathrm{~B}, 858 \mathrm{C}$, and $858 \mathrm{D}$ when compared to the other sites and approach similar levels at the other depths as observed for the previous sites (Table 1 and Fig. 5). These high yields, together with the elevated TOC values at shallow depths (Fig. 4; Davis, Mottl, Fisher, et al., 1992), indicate that migrated bitumens are important and the hydrocarbon signatures can in this case be utilized as indicators for hydrothermal petroleums. Thus, samples with high bitumen yields (yield $>10 \mu \mathrm{g} / \mathrm{cm}^{3}$, shown as solid points on Fig. 5) and/or mature $n$-alkane signatures are defined here as hydrothermal petroleum intervals.

The dominant compound series in the total extracts is $n$-alkanes ranging from $\mathrm{C}_{14}$ to $\mathrm{C}_{35}$ (some of the hydrothermal bitumens have ranges from $n-\mathrm{C}_{10}$ to $>n-\mathrm{C}_{36}$ ), with pristane and phytane as the major isoprenoid alkanes (e.g., Figs. $2 \mathrm{C}, 2 \mathrm{E}, 2 \mathrm{~F}$, and $3 \mathrm{C}$ ). In the relatively unaltered sediments, the $n$-alkanes $>\mathrm{C}_{26}$ have a significant predominance of odd carbon numbers $(\mathrm{CPI}>1.0)$ and $\mathrm{C}_{\max }$ at $\mathrm{C}_{27}$ or $\mathrm{C}_{29}$, which is typical for immature hydrocarbons with an origin from terrestrial higher plants (Simoneit, 1977, 1978). The $n$-alkane patterns $<C_{24}$ with the $\mathrm{UCM}$ of branched and cyclic compounds and the $\mathrm{C}_{\max }$ at $\mathrm{C}_{17}$ are interpreted as typical for autochthonous marine bitumen derived from alteration of microbial detritus (Davis, Mottl, Fisher, et al., 1992).

Hydrothermal petroleums (bitumens) are products of rapid diagenesis/catagenesis and have alkane distributions analogous to those of conventional crude oils (Simoneit and Lonsdale, 1982; Simoneit, 1985, 1990a, 1992a, 1992b, 1993). The carbon number distributions and other geochemical parameters for hydrothermal petroleums generally reflect the source organic matter and the degree of thermal alteration or maturity (Kawka and Simoneit, 1987; Kvenvolden et al., 1986; Simoneit and Lonsdale, 1982; Simoneit, 1985, 1990a). The 

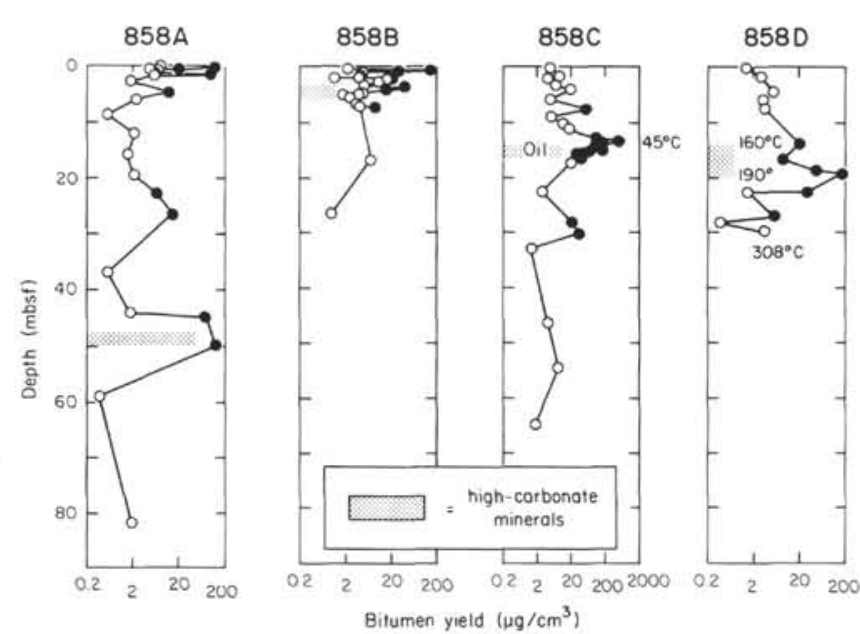

Figure 5. Yields of bitumen extracts for sediments from Site 858. Solid data points are for hydrothermal petroleum and some contemporary in-situ temperatures are given. Intervals with high amounts of carbonate minerals $(5 \%-25 \%$, Davis, Mottl, Fisher, et al., 1992) are also indicated.

hydrothermal bitumen horizons in the cores drilled at Site 858 have diverse $n$-alkane distributions (e.g., Fig. 6; also Davis, Mottl, Fisher, et al., 1992) and variable yields (cf. solid data points in the yield plots of Fig. 5).

Examples (Fig. 6) of immature hydrothermal bitumen are Samples 139-858B-1H-2, 31-32 cm, and 139-858D-1H-1, 67-71 cm, where the odd carbon $n$-alkanes are predominant; intermediate maturity is evident for Sample 139-858C-3H-2, 68-69 cm; full maturity is found for Samples 139-858A-1H-1, 149-150 cm, 139-858C-2H-CC (strong even-to-odd carbon number preference), 139-858D-2H-CC, 37-40 $\mathrm{cm}$, and 139-858D-3P-1, 54-56 cm, where 139-858A-1H-1, 149-150 $\mathrm{cm}$, is partially biodegraded as inferred from the low amounts of hydrocarbons $<n-\mathrm{C}_{22}$ (Simoneit, 1990b); and overmaturity is indicated for Sample 139-858A-6H-CC, consisting primarily of UCM and aromatic hydrocarbons typically generated at high temperatures $\left(>200^{\circ} \mathrm{C}\right.$ or more, see also Fig. 2D). The hydrocarbon pattern of the latter sample is similar to that of the petroleum present in a barite chimney recovered with the deep-submersible Alvin from this vent/mound system (Simoneit et al., 1992).

The CPI is near or less than 1 in the hydrothermal bitumen intervals of Holes 858A, 858B, 858C, and 858D (Fig. 7), which is indicative of full petroleum maturity caused by the high thermal stress. The CPI profiles for all holes remain at values near 1 below the hydrothermal bitumen intervals, consistent with full maturity vs. depth together with a source input of the even-predominance alkanes. The same pattern is observed at Site 857 . The CPI $<1$ in various intervals of Holes $858 \mathrm{~A}, 858 \mathrm{~B}$, and $858 \mathrm{C}$, especially for the hydrothermal petroleum of Sample 139-858C-2H-CC, which has a strong even-carbonnumber predominance over the full range from $n-\mathrm{C}_{16}$ to $n-\mathrm{C}_{34}$ (Figs. $2 \mathrm{E}$ and $6 \mathrm{D}$ ), should be emphasized. This low CPI seems to be a characteristic of these bitumens, as discussed earlier. The variability of surficial CPI values in these holes (Fig. 7) probably reflects different source inputs of marine and terrestrial organic matter, which are then overprinted by the degree of thermal stress or hydrothermal petroleum migration. The square data points in Figure 7 are examples of mixtures of lipids with hydrothermal bitumen, having both a high yield and high CPI.

With the additional samples analyzed, full maturation is still not always evident in the isoprenoid to normal hydrocarbon ratios ( $\mathrm{Pr} /$ $n-\mathrm{C}_{17}$ and $\mathrm{Ph} / n-\mathrm{C}_{18}$, Table 1) for the hydrothermal bitumen zones, but in general these ratios are low below those intervals (cf. Davis, Mottl, Fisher, et al., 1992). Low $\mathrm{Pr} / n-\mathrm{C}_{17}$ and $\mathrm{Ph} / n-\mathrm{C}_{18}$ values $(<0.5)$ are characteristic of basin sediments that are mature (Hunt, 1979). The
$\mathrm{Pr} / \mathrm{Ph}$ ratio fluctuates from 0.2 to 4.6 for these holes, showing no trends with the hydrothermal bitumen intervals. This may reflect the organic matter sources rather than lower temperature maturation.

The overall hydrocarbon signatures of the shallow intervals of the Site 858 sediments with low thermal alteration are similar to those of Sites 856 and 857 , and of shallow gravity cores taken around Site 858 (Simoneit et al., 1992). The hydrocarbons in the near seafloor intervals with high extract yields probably reflect high temperature fluid invasion of the deeper intervals rapidly matured by hydrothermal processes, and petroleum migration both lateral and upward. The hydrothermal petroleum occurs at shallow depths in all holes (above $60 \mathrm{mbsf}$ in Hole 858A, and above $30 \mathrm{mbsf}$ in Holes 858B, 858C, and $858 \mathrm{D}$, Fig. 5). Commonly, there appears to be an accumulation of hydrocarbons, as indicated by an increase in relative yield, in association with zones of high carbonate concentration (e.g., at $50 \mathrm{mbsf}$ in Hole 858A; at 5 mbsf in Hole 858B; at $14 \mathrm{mbsf}$ in Hole 858C; and the 13 to 19 mbsf interval of Hole 858D, Fig. 5; and Davis, Mottl, Fisher, et al., 1992). These carbonates probably act as a cap and are secondary hydrothermal precipitates (e.g., Früh-Green et al., this volume; Boni et al., this volume). Changes in $\mathrm{CPI}, \mathrm{Pr} / n-\mathrm{C}_{17}, \mathrm{Pr} / n-\mathrm{C}_{18}$, and $\mathrm{Pr} / \mathrm{Ph}$ also occur within the same intervals.

\section{Temperature Regime and Petroleum Formation Processes}

The changes in extractable hydrocarbons at Sites 855 and 856 have been discussed in terms of source and maturation changes. The lipid/ bitumen parameters described for these sites can be used to constrain sources and degrees of maturation in these sediments because the potential influences of other processes, including migration and biodegradation, can be ruled out. Specifically, it is not indicated that hydrocarbon compositions are influenced to any significant extent at Sites 855 and 856 by primary or secondary migration processes or by biodegradation (Davis, Mottl, Fisher, et al., 1992). The general processes that affect sedimentary organic matter are source, maturation, expulsion or primary migration, secondary and tertiary migration, and biodegradation. Primary oil migration in conventional basins, which is the rate-limiting step in the petroleum generation process (Lewan, 1987), is the initial expulsion of oil from the fine-grained source rock, where it is first formed, into a more permeable carrier or reservoir bed, such as a silt or sand or porous limestone. Secondary and tertiary migration processes occur as the petroleum moves and fractionates further within the carrier or reservoir beds (Hunt, 1979). In hydrothermal systems these consecutive processes are compressed into a single continuum due to rapid fluid passage (Simoneit, 1992a, 1992b; Didyk and Simoneit, 1989, 1990). The hydrothermal process also differs based on the extraction efficiency of the products by the fluid passing through the sediment (Simoneit, 1992a, 1992b, 1993; Didyk and Simoneit, 1989, 1990). These data (Davis, Mottl, Fisher, et al., 1992) indicate that hydrothermal bitumen migration, including both primary expulsion and migration of generated hydrocarbons from fine-grained intervals and secondary migration of hydrocarbons within more permeable sand and silt layers, has not occurred in the sediments at either Site 855 or 856 . Thus, these hydrocarbon mixtures indicate rapid maturation by accelerated diagenesis resulting from high regional heat flow, and not from hydrothermal alteration by fluid transgression.

The overall hydrocarbon signatures of the upper intervals of the Site 857 sediments are similar to those of Site 856 and of shallow gravity cores taken near the Middle Valley hydrothermal vents (Simoneit et al., 1992). The hydrocarbons in the deeper intervals indicate rapid maturation by accelerated diagenesis, probably resulting from high regional heat flow rather than from hydrothermal alteration. The approximate present-day temperatures of the sediments can be estimated by extrapolating current subsurface temperatures from the surface heat-flow curves (Davis, Mottl, Fisher, et al., 1992). This indicates that the higher molecular weight compounds $\left(>\mathrm{C}_{14}\right)$ are surviving in these sediments to temperatures above those typical of the oil generation window (Hunt, 1979; Tissot and Welte, 1984). For example, long- 

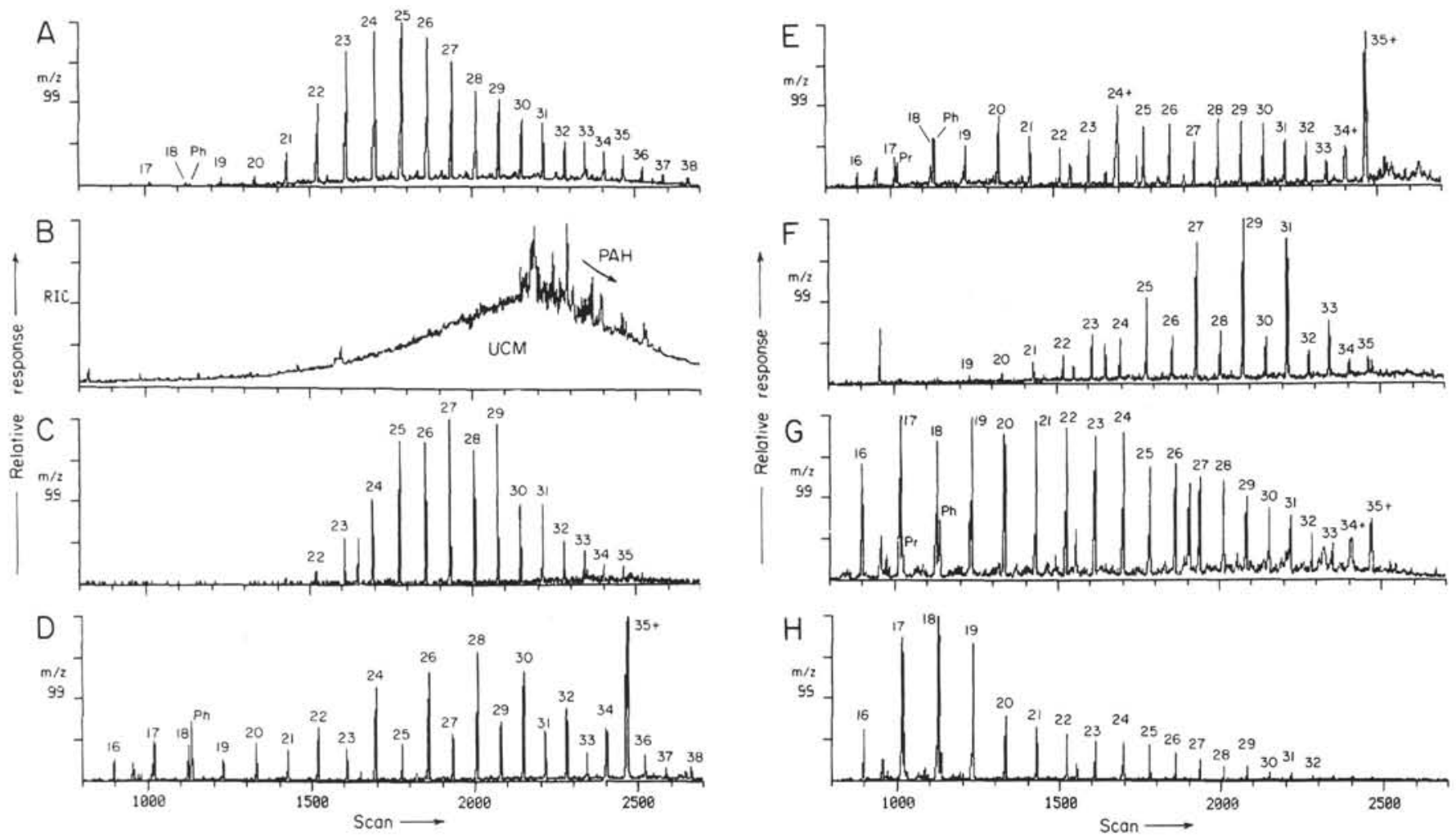

Figure 6. Mass fragmentograms of $\mathrm{m} / \mathrm{z} 99$ for selected samples from Site 858 . A. Sample 139-858A-1H-1, 149-150 cm. B. Sample 139-858A-6H-CC (RIC, m/z 99 has no peaks attributable to $n$-alkanes). C. Sample 139-858B-1H-2, 31-32 cm. D. Sample 139-858C-2H-CC. E. Sample 139-858C-3H-2, $68-69 \mathrm{~cm}$. F. Sample 139-858D-1H-1, 67-71 cm. G. Sample 139-858D-2H-CC. H. Sample 139-858D-3P-1, 54-56 cm. Numbers refer to the carbon chain length of the $n$-alkanes. Pr $=$ pristane, $\mathrm{Ph}=$ phytane, $+=$ coeluting isoprenoid hydrocarbon, $\mathrm{UCM}=$ unresolved complex mixture, $\mathrm{PAH}=$ polynuclear aromatic hydrocarbons.

chain alkanes $\left(>\mathrm{C}_{23}\right)$ are still measurable at 433 mbsf in Hole $857 \mathrm{C}$, corresponding to a current temperature of $\sim 270^{\circ} \mathrm{C}$, considerably beyond the maximum range of $135^{\circ}$ to $150^{\circ} \mathrm{C}$ normally claimed as the end of the oil window in conventional basins (Hunt, 1979). In addition, the CPI does not decrease to 1.0, diagnostic of maturation, until these sediments reach temperatures above $150^{\circ} \mathrm{C}$ at depths below $230 \mathrm{mbsf}$. Thus, the thermal alteration/destruction of these aliphatic hydrocarbons typical of petroleum is not complete up to temperatures of $270^{\circ} \mathrm{C}$ at 433 mbsf in Hole 857C (Davis, Mottl, Fisher, et al., 1992). Their survival is probably the result of the young age of the sediments $(<250,000$ yr; Davis, Mottl, Fisher, et al., 1992); that is, short residence time at high temperatures, as both time and temperature must be considered in maturation processes, which respond exponentially to temperature and linearly to time (Hunt, 1979; Tissot and Welte, 1984).

The approximate contemporary temperatures of the hydrothermal petroleum zones observed for Holes $858 \mathrm{~A}, 858 \mathrm{~B}$, and $858 \mathrm{C}$ can be estimated to range from $3^{\circ}$ to $70^{\circ} \mathrm{C}$ by extrapolating current subsurface temperatures from the heat-flow and temperature data (Davis, Mottl, Fisher, et al., 1992). The lowest temperature commonly cited for the beginning of the conventional oil generation window is $50^{\circ} \mathrm{C}$, with peak generation occurring at about $80^{\circ}$ to $100^{\circ} \mathrm{C}$ (Hunt, 1979; Tissot and Welte, 1984). Thus, these temperatures appear to be too low to have generated the observed amounts of hydrothermal petroleum in situ. Migration and deposition of bitumen into those intervals is more likely particularly into zones where hydrothermal flow may also have caused capping by carbonate precipitation (Davis, Mottl, Fisher, et al., 1992). Bitumen concentrations in the intervals below the hydrothermal petroleum zones are low, indicating that the bitumen which had formed there migrated either upward and laterally or laterally with hydrothermal fluids (Fig. 5).

The measured temperature at $20.9 \mathrm{mbsf}$ in Hole $858 \mathrm{D}$ was $>208^{\circ} \mathrm{C}$, which indicates a gradient of about $10^{\circ} \mathrm{C} / \mathrm{m}$. The present zones of hydrothermal petroleum (14 to $28 \mathrm{mbsf}$ ) have experienced high tem-
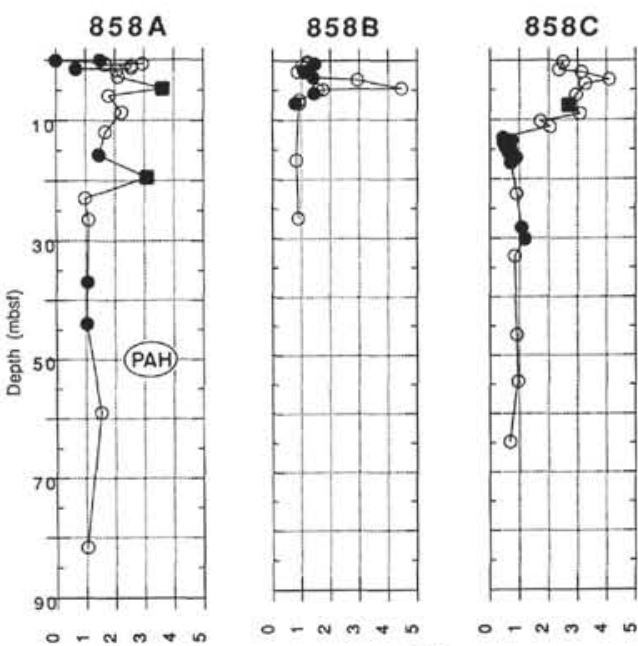

858D
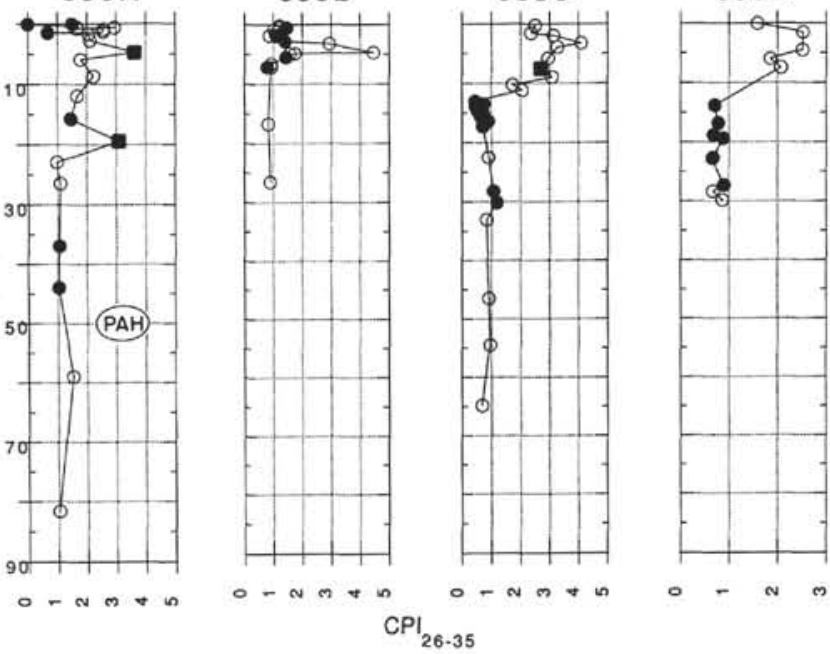

Figure 7. Carbon preference index $\left(\mathrm{C}_{26}\right.$ to $\left.\mathrm{C}_{35}\right)$ for the $n$-alkanes in the bitumen extracts of sediments from Site 858 . Solid data points are for hydrothermal bitumen (solid squares are mixtures of bitumen and lipids).

peratures, possibly as high as $280^{\circ} \mathrm{C}$, based on nearby vent fluid and downhole temperature measurements (Davis, Mottl, Fisher, et al., 1992). With such high temperatures, bitumen is unlikely to survive for any length of time. Therefore, it is postulated that (1) these hydrocarbons have only recently migrated with hydrothermal fluids into this interval, (2) they are currently being generated and/or migrating, or (3) they were generated recently as the surrounding sediments were exposed to a pulse of hot fluid. It should be noted that these hydrother- 


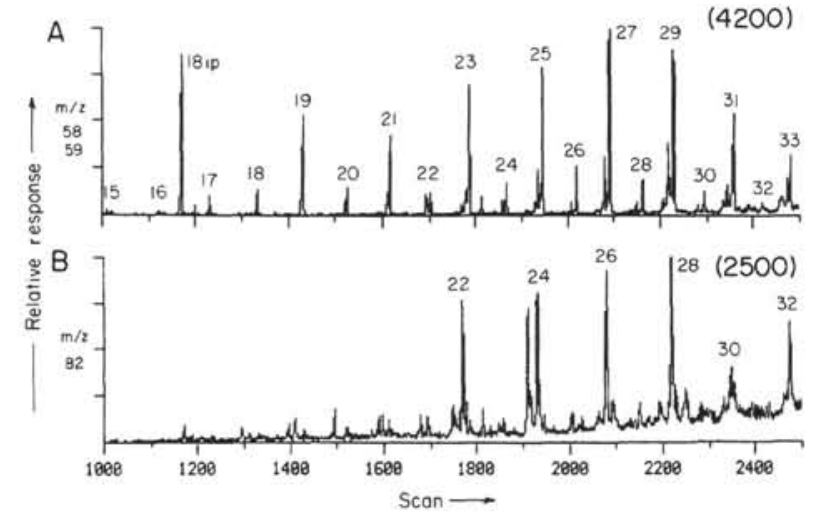

Figure 8. Representative mass fragmentograms for the carbonyl compounds in the bitumen extract of an immature sediment, Sample 139-855D-4R-CC: (A) $\mathrm{m} / \mathrm{z} 58+59, n$-alkan-2-ones, and (B) $\mathrm{m} / \mathrm{z} 82, n$-alkanals. Numbers refer to carbon chain length, $18 \mathrm{ip}=6,10,14$-trimethylpentadecan-2-one.

mal petroleum zones of Site 858 with variable compound compositions are considerably different from those of Hole 857C, where only trace amounts of bitumen were found at depth which were generated in situ reflecting both the organic matter sources and the highest formation temperatures (Davis, Mottl, Fisher, et al., 1992).

\section{Biomarker Data}

These samples contain a full spectrum of biomarkers from the biogenic precursors to the fully mature geological products (e.g., sterols to steranes). This is characteristic of hydrothermal organic matter alteration and is analogous to that observed elsewhere (e.g., Brault and Simoneit, 1988; Brault et al., 1989; Kawka and Simoneit, 1987; Simoneit, 1985, 1990a, 1992b; Simoneit et al., 1984). These samples exhibit the effects of thermal alteration on endogenous sedimentary organic matter, as well as the migrational mixing of hydrothermal petroleum with residual sedimentary lipids.

\section{Immature Precursors}

The biomarkers are immature in the upper sections of all holes and maturation is observed vs. sub-bottom depth, except in samples where mature or overmature hydrothermal bitumen or hot fluid invaded the section. The occurrences of the various biomarker classes and key maturity parameters are summarized for selected samples in Table 2. The bitumen extracts of the upper sediment sections of all sites contain $\mathrm{C}_{37}$ to $\mathrm{C}_{39}$ alkenones that are altered to unknown products at elevated in-situ temperatures. These compounds are generally used as indicators of past sea-surface temperatures and are discussed in a separate paper (Simoneit et al., this volume).

A preliminary search was made for potential precursors responsible for the enhancement of the even-carbon-chain length $n$-alkanes in the mature oils. As discussed earlier, the $n$-alkanols and/or $n$-alkanoic acids in the extractable lipids or bound in the organic detritus (e.g., as parts of membrane residues) could be these precursors. The $n$-alkanoic acids are not amenable for analysis in these total extracts because they are not esterified. The $n$-alkanols were also not detectable in these total extracts because their mass spectra as the un-derivatized compounds are not characteristic or easily resolved by a key ion search. Normal alkan-2-ones, generally ranging from $\mathrm{C}_{15}$ to $\mathrm{C}_{33}$ with a strong odd carbon number predominance, are present in many of the immature sediment extracts (e.g., Fig. 8A). These compounds decrease in concentration in the more mature samples but retain the odd carbon number predominance. Thus, the $n$-alkan-2-ones with the odd carbon predominance are not the precursors of the even-chain nalkanes. Phytone (6,10,14-trimethylpentadecan-2-one) is usually the dominant ketone (e.g., Fig. 8A). It is an oxidation product of phytol from chlorophyll. A trace series of $n$-alkanals, ranging from $\mathrm{C}_{18}$ to $\mathrm{C}_{32}$ with a strong even-carbon-number predominance is found in some of the extracts (e.g., Fig. 8B). These aldehydes may be primary components derived from terrestrial higher plant wax or secondary oxidative derivatives from various lipid sources. Whether they are reduced to even-chain $n$-alkanes would need to be determined by further work.

Sterols (I, all structures cited are given in the Appendix) are major components in the upper sections of all holes and range from $\mathrm{C}_{27}$ to $\mathrm{C}_{29}$ (e.g., Figs. 9A and 9D). The general distribution for the samples
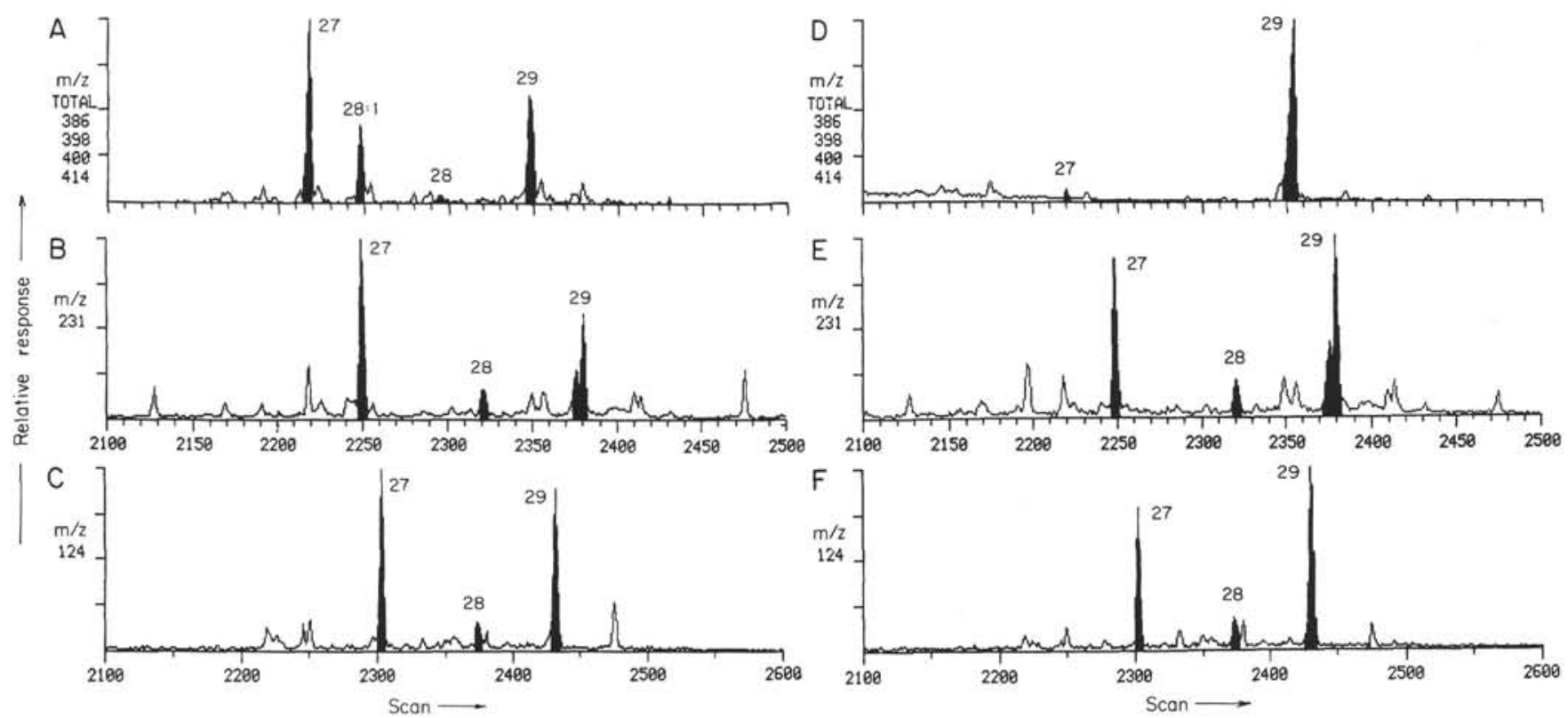

Figure 9. Representative mass fragmentograms for the steroid precursors of steranes in the bitumen extracts of sediments from Leg 139. Sterols (molecular ions 386, 398, 400 and 414 summed). A. Sample 139-855D-4R-CC. B. Sample 139-857A-8H-2, 95-99 cm. C. Sample 139-857A-8H-2, 95-99 cm. D. Sample 139-858A-1H-1, 149-150 cm, stanones (m/z 231, key ion). E. Sample 139-857C-6R-CC, stenones (m/z 124, key ion). F. Sample 139-857C-6R-CC. Numbers refer to carbon skeleton, and 28:1 $=24$-methylcholesta-5,22-dien-3 $\beta$-ol.) 
Table 2. Presence and maturity parameters of biomarkers.

\begin{tabular}{|c|c|c|c|c|c|c|c|c|c|c|}
\hline \multirow[b]{2}{*}{$\begin{array}{l}\text { Core, section, } \\
\text { interval }(\mathrm{cm})\end{array}$} & \multirow[b]{2}{*}{$\begin{array}{l}\text { Depth } \\
\text { (mbsf) }\end{array}$} & \multicolumn{4}{|c|}{ Immature biomarkers } & \multicolumn{5}{|c|}{ Mature biomarkers } \\
\hline & & Sterols & Stenones & Stanones & Amyrins & $\begin{array}{c}\mathrm{C}_{31} \text { homohopane: } \\
\frac{22 \mathrm{~S}}{(22 \mathrm{~S}+22 \mathrm{R})}\end{array}$ & $\frac{\mathrm{C}_{27} \text { sterane, } 20 \mathrm{R}}{\mathrm{C}_{29} \text { sterane, } 20 \mathrm{R}}$ & $\frac{C_{29} \text { sterane: }}{20 \mathrm{~S}}$ & $\begin{array}{l}\frac{\mathrm{C}_{27} \text { diasterane: }}{20 \mathrm{~S}} \\
(20 \mathrm{~S}+20 \mathrm{R})\end{array}$ & $\begin{array}{l}\text { 3,3,7-trimethyl-1, 2, 3,4- } \\
\text { tetrahydrochrysene }\end{array}$ \\
\hline $\begin{array}{l}\text { 139-855D- } \\
\text { 4R-CC }\end{array}$ & 108.5 & +++ & + & + & +++ & 0.48 & 0.58 & 0.38 & 0.50 & ++ \\
\hline $\begin{array}{l}\text { 139-856 A- } \\
2 \mathrm{H}-\mathrm{CC}\end{array}$ & 12.0 & + & + & + & + & 0.35 & 0.29 & 0.22 & & - \\
\hline $\begin{array}{l}139-857 \mathrm{~A}- \\
1 \mathrm{H}-1,0-1 \\
8 \mathrm{H}-2,95-99\end{array}$ & $\begin{array}{r}1.9 \\
62.0\end{array}$ & $\overline{+}$ & $\overline{-+}$ & $\overline{++}$ & $\overline{+}$ & 0.38 & $\stackrel{0.33}{-}$ & 0.27 & & ++ \\
\hline $\begin{array}{l}\text { 139-857C- } \\
6 \mathrm{R}-\mathrm{CC} \\
\text { 9R-CC } \\
48 \mathrm{R}-1,73-75\end{array}$ & $\begin{array}{r}95.0 \\
124.0 \\
409.0\end{array}$ & \pm & $\begin{array}{l}+ \\
+ \\
+\end{array}$ & $\begin{array}{l}+++ \\
++ \\
++\end{array}$ & \pm & $\begin{array}{l}0.31 \\
0.29 \\
0.58\end{array}$ & $\begin{array}{c}0.23 \\
0.82 \\
-\end{array}$ & $\begin{array}{l}0.23 \\
0.15\end{array}$ & $\begin{array}{l}0.49 \\
0.50\end{array}$ & $\begin{array}{l}++ \\
+\end{array}$ \\
\hline $\begin{array}{l}139-858 \mathrm{~A}- \\
1 \mathrm{H}-1,149-150 \\
4 \mathrm{H}-4,52-56 \\
6 \mathrm{H}-\mathrm{CC}\end{array}$ & $\begin{array}{r}1.5 \\
26.5 \\
50.0\end{array}$ & $\stackrel{++}{-}$ & E & \pm & $\bar{z}$ & $\begin{array}{l}0.63 \\
0.60\end{array}$ & 1.40 & 0.45 & 0.61 & $\bar{z}$ \\
\hline $\begin{array}{l}139-858 \mathrm{~B}- \\
1 \mathrm{H}-1,48-52 \\
1 \mathrm{H}-2,31-32 \\
1 \mathrm{H}-2,42-44\end{array}$ & $\begin{array}{l}0.5 \\
1.8 \\
1.9\end{array}$ & $\begin{array}{l}+ \\
+ \\
+\end{array}$ & $\begin{array}{c}+++ \\
+ \\
+\end{array}$ & $\begin{array}{l}+++ \\
+ \\
+\end{array}$ & $\bar{z}$ & $\begin{array}{l}0.44 \\
0.30 \\
0.40\end{array}$ & $\begin{array}{l}1.30 \\
0.50\end{array}$ & $\begin{array}{l}0.41 \\
0.38\end{array}$ & $\begin{array}{l}0.56 \\
0.50\end{array}$ & $\bar{z}$ \\
\hline $\begin{array}{l}139-858 \mathrm{C}- \\
2 \mathrm{H}-5,71-73 \\
2 \mathrm{H}-\mathrm{CC} \\
3 \mathrm{H}-1,44-45 \\
3 \mathrm{H}-2,68-69 \\
3 \mathrm{H}-2,110-115\end{array}$ & $\begin{array}{l}10.2 \\
13.0 \\
13.5 \\
15.0 \\
15.5\end{array}$ & $\begin{array}{l}z \\
\bar{z}\end{array}$ & $\begin{array}{l}\bar{z} \\
\bar{z}\end{array}$ & $\begin{array}{l}\bar{z} \\
\bar{z}\end{array}$ & $\begin{array}{l}\bar{z} \\
\bar{z}\end{array}$ & $\begin{array}{l}0.23 \\
0.29 \\
0.55 \\
0.55 \\
0.55\end{array}$ & $\begin{array}{l}0.22 \\
1.60 \\
3.20 \\
1.10 \\
1.90\end{array}$ & $\begin{array}{l}0.11 \\
0.07 \\
0.41 \\
0.45 \\
0.39\end{array}$ & $\begin{array}{l}0.38 \\
0.55 \\
0.65 \\
0.58\end{array}$ & $\begin{array}{l} \pm \\
= \\
=\end{array}$ \\
\hline $\begin{array}{l}\text { 139-858D- } \\
1 \mathrm{H}-1,0-1 \\
1 \mathrm{H}-1,67-70 \\
1 \mathrm{H}-4,146-150 \\
2 \mathrm{H}-\mathrm{CC}, 37-40 \\
3 \mathrm{P}-1,54-56\end{array}$ & $\begin{array}{r}0.0 \\
0.7 \\
6.0 \\
18.8 \\
19.3\end{array}$ & $\begin{array}{l}+ \\
+ \\
+ \\
-\end{array}$ & $\begin{array}{l}++ \\
+ \\
+ \\
+\end{array}$ & $\begin{array}{l}+ \\
+ \\
+ \\
+\end{array}$ & $\begin{array}{l}+ \\
+ \\
+ \\
+\end{array}$ & $\begin{array}{l}0.23 \\
0.35 \\
0.33 \\
0.53 \\
0.50\end{array}$ & $\begin{array}{l}0.38 \\
0.73\end{array}$ & $\begin{array}{l}0.27 \\
0.30\end{array}$ & 0.57 & $\begin{array}{l} \pm \\
\pm \\
=\end{array}$ \\
\hline
\end{tabular}

Note: Presence indicated as: $++=$ major components, $++=$ intermediate, $+=$ minor to trace, $-=$ not detectable or sample too small.

analyzed is cholesterol $(\mathrm{I}, \mathrm{R}=\mathrm{H}$ ) dominant or equal to $\beta$-sitosterol (I, $\mathrm{R}=\mathrm{C}_{2} \mathrm{H}_{5}$ ), and one case with $\beta$-sitosterol predominant. Also, 24methylcholesta-5,22-dien-3-ol (II) is present in these sterol suites, although it generally occurs as an ester or ether in sediments (Brassell et al., 1983). This compound, cholesterol, and possibly part of the $\beta$-sitosterol are interpreted to be derived from marine organic detritus. The sole dominance of $\beta$-sitosterol (Fig. 9D) or a portion of this compound in the other samples is interpreted to originate from terrigenous higher plant sources.

Alteration of sterols by accelerated diagenesis due to thermal stress is observed to yield stenones (III) and stanones (IV) with the same range from $C_{27}$ to $C_{29}\left(C_{26}\right.$ is not detectable and $C_{30}$ is present as a minor component) (e.g., Figs. 9B, 9C, 9E, and 9F). 24-Methylcholesta-4,22-dien-3-one or 24-methylcholest-22-en-3-one are not detectable, indicating that the precursor sterol (II) is altered to other products. Stanols, sterenes (e.g., $\Delta^{2}, \Delta^{3}$, or $\Delta^{4}$ ) and steradienes (e.g., $\left.\Delta^{2},{ }^{4}\right)$ are not detectable in any sample. This suggests that products from dehydration reactions of sterols, as were described for sediments from Bransfield Strait (Brault and Simoneit, 1988), are not preserved in this sample set.

Terrestrial triterpenoid markers are present in the shallow sections of all holes, but their mature derivatives are present as traces owing to the high concentrations of hopanes that are generated during thermal maturation. The dominant biological precursors identified are $\alpha$-amyrin $(\mathrm{V}, \mathrm{R}=\mathrm{OH}$ ) and $\beta$-amyrin (VI, $\mathrm{R}=\mathrm{OH}$ ) (Fig. 10A) from higher plants (Brassell et al., 1983; Simoneit, 1986). These compounds are altered primarily to $\alpha$-amyrone (urs-12-en-3-one, $\mathrm{V}, \mathrm{R}=$ $\mathrm{O}$ ) and $\beta$-amyrone (olean-12-en-3-one, $\mathrm{VI}, \mathrm{R}=\mathrm{O}$ ) and lesser amounts of olean-12-ene (VII) and urs-12-ene (Figs. 10B and 10C).

Various triterpenoid precursors for the hopanes are found in the shallow sections of all holes. Diploptene (VIII) occurs in the upper sections and is altered to $17 \beta(\mathrm{H})$-hop-21-ene (IX) and then to hop- 17(21)-ene (X) (Figs. 11A and 11B). This is the same trend of thermally accelerated diagenesis as was described for Guaymas Basin surficial sediments and immature bitumens (Simoneit et al., 1979, 1984; Simoneit and Philp, 1982), and for Bransfield Strait sediments (Brault and Simoneit, 1988). Major amounts of oxygenated species, comprised mainly of $17 \beta(\mathrm{H}), 21 \beta(\mathrm{H})$-bishomohopan-32-ol (XI) and $17 \beta(\mathrm{H})$-22,29,30-trisnorhopan-21-one (XII), are present in the shallow samples (Figs. 11A and 11B),

Fernene (XIII, $\left.\Delta^{9(11)}\right)$ is found in some samples (e.g., Fig. 11E) and is interpreted to be an indicator for bacterial detritus (Simoneit, 1986). An unknown triterpene is also present in some shallow sediment samples (e.g., Fig. 11G, peak 8, the mass spectrum has the following fragmentation pattern: $\mathrm{m} / \mathrm{z} 69(70), 81(25), 151(100), 189(20), 191(22)$, $206(10), 410(30))$.

\section{Sterane Maturation}

Sterane hydrocarbons, useful for oil-source rock and maturity comparisons (Mackenzie et al., 1982; Seifert, 1978; Seifert and Moldowan, 1978, 1979), also exhibit differences among these samples. Examples of the sterane maturation in this sample suite are given in Figure 12 and the parameter data are listed in Table 2. The steranes have distributions with $\mathrm{C}_{27}$ dominant or with $\mathrm{C}_{29}$ dominant, and in all cases $\mathrm{C}_{28}$ is intermediate with $\mathrm{C}_{30}$ as a minor component. The $\mathrm{C}_{27}(20 \mathrm{R}) / \mathrm{C}_{29}$ (20R) ratios range from 0.22 to 3.2 for the samples analyzed (Table 2), in which values $<1$ indicate a stronger influx of $\mathrm{C}_{29}$ terrestrial marker steroids. This assumes a constant influx of marine derived $\mathrm{C}_{29}$ steroid residues (Volkman, 1986).

Sample 139-858C-2H-CC (13 mbsf) contains significant concentrations of $\mathrm{C}_{27}$ to $\mathrm{C}_{30}$ steranes (XX) primarily with the $5 \alpha(\mathrm{H}), 14 \alpha(\mathrm{H})$, $17 \alpha(\mathrm{H})-20 \mathrm{R}$ and smaller amounts of the thermally less stable $5 \beta(\mathrm{H})$, $14 \alpha(\mathrm{H}), 17 \alpha(\mathrm{H})-20 \mathrm{R}$ configurations (Kawka and Simoneit, 1987). Sam- 


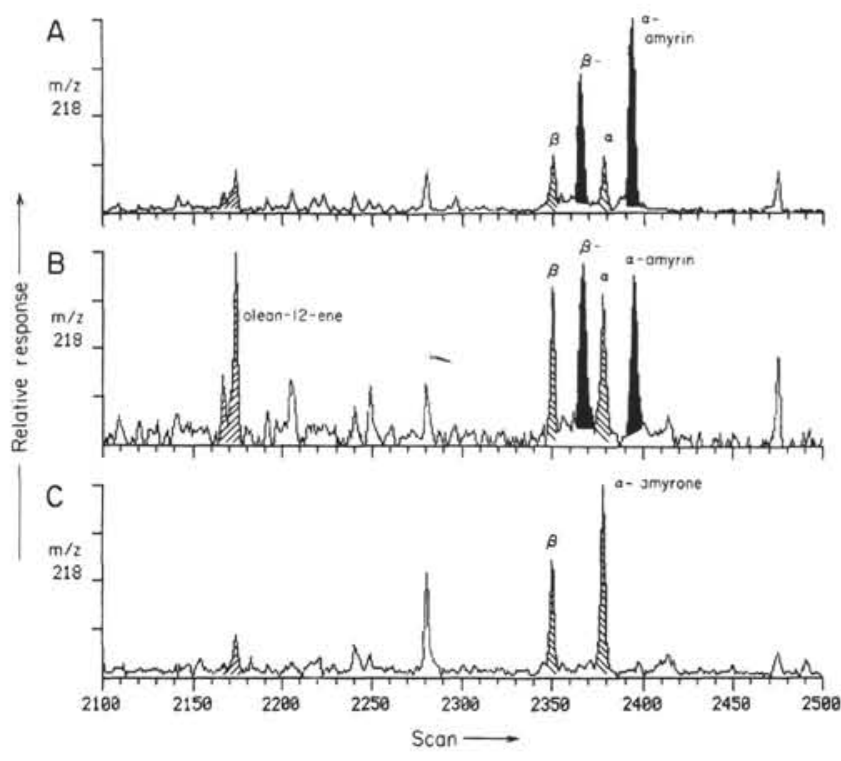

Figure 10. Representative mass fragmentograms of $\mathrm{m} / \mathrm{z} 218$ for the terrestrial triterpenoid biomarkers in the bitumen extracts of Leg 139 sediments. A. Sample 139-855D-4R-CC. B. Sample 139-857C-6R-CC. C. Sample 139$858 \mathrm{D}-1 \mathrm{H}-4,146-150 \mathrm{~cm}$. The transformation proceeds from amyrins to amyrones to oleanenes to oleananes.

ple $139-858 \mathrm{C}-3 \mathrm{H}-1,44-45 \mathrm{~cm}$, which is $50 \mathrm{~cm}$ deeper, exhibits the onset of epimerization at C-20, which occurs during thermal maturation (Seifert and Moldowan, 1978; Mackenzie et al., 1980). The epimerization ratio at $\mathrm{C}-20$,

$$
\left(\frac{20 S}{20 S+20 R}\right)
$$

of $\mathrm{C}_{29}$, increases from 0.07 to 0.41 for these two samples. Full maturity with a $\mathrm{C}_{29}$ epimerization ratio of 0.45 is found for the next deepest sample at $15.2 \mathrm{mbsf}(139-858 \mathrm{C}-3 \mathrm{H}-2,68-69 \mathrm{~cm})$ and also for the example in Figures 12D-12F (Sample 139-858A-1H-1, 149-150 cm). As the maturity increases, additional isomerization is evident as the $5 \mathrm{a}(\mathrm{H}), 14 \mathrm{~b}(\mathrm{H}), 17 \mathrm{~b}(\mathrm{H})-20 \mathrm{R}$ and 20S-steranes (XXI, e.g., Figs. 12C and $12 \mathrm{E})$, and the diasteranes (XXII, 13b $(\mathrm{H}), 17 \mathrm{a}(\mathrm{H})-20 \mathrm{~S} / \mathrm{R})$ increase in relative concentration to the regular steranes. The diasterane epimerization parameter,

$$
\left(\frac{20 S}{20 S+20 R}\right)
$$

for $\mathrm{C}_{27}$, varies from 0.38 to 0.65 for these samples (Table 2).

These sterane compositions are analogous to those reported earlier for shallow samples from the hydrothermal vent area near Site 858 (Simoneit et al., 1992). The maturation also parallels the data for hydrothermal petroleums from Guaymas Basin and Escanaba Trough (Kawka and Simoneit, 1987; Simoneit, 1985; Kvenvolden and Simoneit, 1990).

\section{Triterpane Maturation}

The hopanes undergo maturation from immature precursors, including the $17 \beta(\mathrm{H}), 21 \beta(\mathrm{H})$-hopanes (XIV) and moretanes $(17 \beta(\mathrm{H})$, $21 \alpha(\mathrm{H})$-hopanes, $\mathrm{XV})$, to the $17 \alpha(\mathrm{H}), 21 \beta(\mathrm{H})$-hopanes (XVI). The configuration of the biological precursors is $17 \beta(\mathrm{H}), 21 \beta(\mathrm{H})$ for this series as the R epimer at C-22 for the extended homologs $>\mathrm{C}_{31}$ (Ensminger et al., 1974, 1977). Maturation converts the precursors to the thermodynamically most stable configuration of $17 \alpha(\mathrm{H}), 21 \beta(\mathrm{H})$, with the $\mathrm{S}$ and $\mathrm{R}$ epimers at $\mathrm{C}-22$ for the extended homologs $>\mathrm{C}_{31}$ at an equilibrium ratio

$$
\left(\frac{S}{S+R}\right)
$$

of about 0.6 (Ensminger et al., 1974, 1977; Seifert and Moldowan, 1978). Typical examples for this series are shown in Figure 11 and the maturity parameters are given in Table 2 .

Low levels of $17 \alpha(\mathrm{H}), 21 \beta(\mathrm{H})$-hopanes are detectable in the immature sections of all sites along with oxygenated and unsaturated precursors (e.g., Figs. 11A, 11B, and 11E). The homohopane epimer ratios in such sections vary from 0.23 to 0.40 , are still immature, and yet no significant amounts of the $17 \beta(\mathrm{H}), 21 \beta(\mathrm{H})$ - and $17 \beta(\mathrm{H})$, $21 \alpha(\mathrm{H})$-hopanes are present. This is in contrast to the shallow sediments described earlier from the area of Site 858, where the hopanes contain the $17 \beta(H), 21 \beta(H)$ series (Simoneit et al., 1992). Significant $17 \alpha(\mathrm{H}), 21 \beta(\mathrm{H})$-hopanes are found in deeper sections; for example, at about $13 \mathrm{mbsf}$ in Hole $858 \mathrm{C}$ (Figs. 11C and 11D). The homohopane maturity parameter increases from 0.29 to 0.55 over a 50 -cm increase in depth. The hopanes range from $\mathrm{C}_{27}$ to $\mathrm{C}_{35}$ and the dominant homologs are $C_{35}, C_{30}$, and $C_{32}$, for which the $C_{32}$ to possibly the $C_{35}$ homologs are derived from the respective hopanols found in the immature sections. The mature $17 \alpha(\mathrm{H}), 21 \beta(\mathrm{H})$-hopanes are predominant over the moretanes (XV) and only minor amounts of the $17 \beta(\mathrm{H})$, $21 \beta(\mathrm{H})$-hopanes were detectable (Fig. 11D).

Traces of mature $17 \alpha(\mathrm{H}), 21 \beta(\mathrm{H})$-hopanes are found in the reference hole (e.g., Sample 139-855D-4R-CC, Fig. 11F), indicating accelerated diagenesis in situ or influx of mature bitumen with fluids at some time in the past. An example of a fully mature hopane signature is shown in Figure 11G, where the homohopane epimer ratio is 0.63 and the $\mathrm{C}_{35}$ and $\mathrm{C}_{32}$ extended hopanes have been cracked to the lower homologs which possibly enhances the $17 \alpha(\mathrm{H}), 21 \beta(\mathrm{H})$-29-norhopane concentration. This distribution is analogous to that described earlier for a seabed petroleum from the Site 858 area, except that sample also had a major amount of gammacerane (Simoneit et al., 1992). These hopane maturation trends are analogous to those described for sediments and hydrothermal petroleums from Guaymas Basin and Escanaba Trough (Kawka and Simoneit, 1987; Kvenvolden and Simoneit, 1990; Simoneit et al., 1984).

The amyrins, amyrones, and olean-12-ene characterized in the immature sections are in part altered to oleananes. The $18 \alpha(\mathrm{H})$ - and $18 \beta(\mathrm{H})$-oleananes (XVII) elute just prior to $17 \alpha(\mathrm{H}), 21 \beta(\mathrm{H})$-hopane by GC or GC-MS (Ekweozor and Udo, 1988) and have been utilized as maturity parameters for terrestrial organic matter. These two isomers elute as a minor, unresolved peak in most of these samples (Fig. 11 , peak 0 ). This peak is also present in the data for the shallow cores reported earlier (Simoneit et al., 1992). A degraded triterpane residue, namely 3,3,7-trimethyl-1,2,3,4-tetrahydrochrysene (XVIII), is found as a major compound in the immature sections of most holes. This aromatic, degraded triterpenoid is interpreted to be derived from higher plants probably by microbial, photochemical, or photomimetic processes during sedimentation (e.g., Hauke et al., 1992; Corbet et al., 1980). Gammacerane (XIX), which was a dominant triterpane present in the seabed hydrothermal bitumen from the vent area of Site 858 (Simoneit et al., 1992), was not detectable except as a trace component in Sample 139-855D-4R-CC (Fig. 11F). A significant amount of an unknown pentacyclic triterpane (major MS fragments: 191 (100), 369 (7), 397 (10), 412 (5)) is also present in Sample 139-858D-1H-4, 146-150 cm (Fig. 11E).

\section{Polynuclear Aromatic Hydrocarbons}

The relative concentrations of selected polynuclear aromatic hydrocarbons (PAHs) and various ratios in these samples are given in Table 3. The low-molecular-weight aromatic and alkyl aromatic hydrocarbons are strongly depleted in the hydrothermal petroleums of Middle Valley (Table 3; Simoneit et al., 1992). Thus, alkyl naphthalenes and phenanthrene/alkyl phenanthrenes are present at significant concentrations only in Sample 139-858D-1H-4, 146-150 cm, although all samples contain trace amounts of the phenanthrene series, fluoranthene, pyrene, and chrysene. This indicates that these aromatics were removed and/or introduced into these shallow sub-bottom 

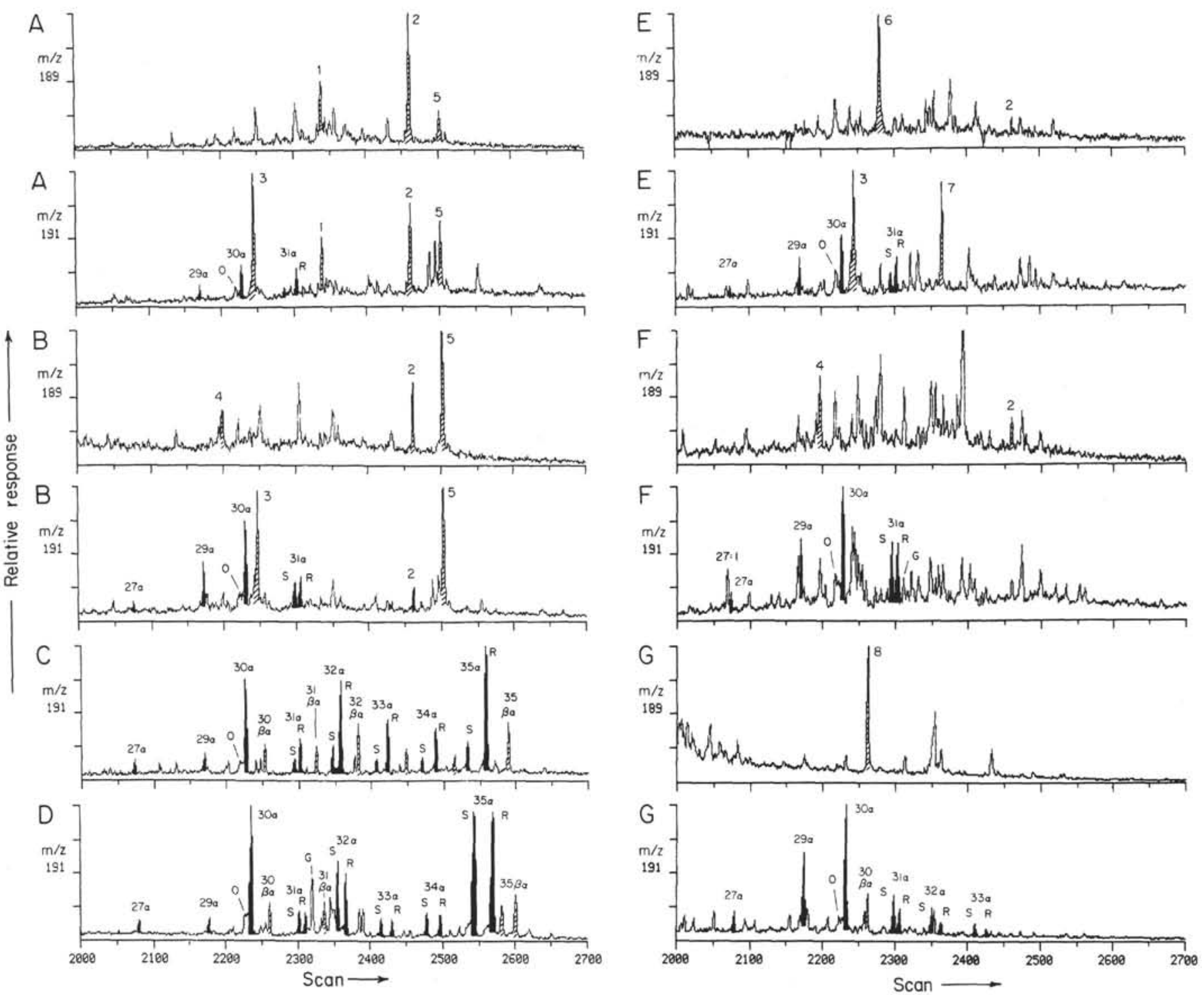

Figure 11. Representative mass fragmentograms of m/z 189 and 191 for the triterpenoid hydrocarbons in the bitumen of Leg 139 sediments. A. Sample 139-858D-1H-1, 0 cm. B. Sample 139-858B-1H-1, 48-52 cm. C. Sample 139-858C-2H-CC. D. Sample 139-858C-3H-1, 44-45 cm. E. Sample 139-858D-1H-4, 146-150 cm. F. Sample 139-858D-4R-CC. G. Sample 139-858A-1H-1, 149-150 cm. (1 = 17ß(H)-hop-21-ene; $2=$ diploptene; 3 = 17ß(H)-22,29,30-trisnorhopan21-one; 4 = hop-17(21)-ene; $5=17 \beta(\mathrm{H}), 21 \beta(\mathrm{H})$-homohopan-31-ol; $6=$ fernene; $7=$ unknown $\mathrm{C}_{30}$ triterpane; $8=$ unknown $\mathrm{C}_{30}$ triterpene; $\mathrm{O}=$ oleananes, $\mathrm{G}=$ gammacerane; $i \alpha=17 \alpha(\mathrm{H}), 21 \beta(\mathrm{H})$-hopane series, with $\mathrm{S}$ and $\mathrm{R}$ entantiomers at $\mathrm{C}-22 ; i \beta \alpha=17 \beta(\mathrm{H}), 21 \alpha(\mathrm{H})$-hopane series, i.e., moretanes.)

sediments by aqueous fluids and that the lower molecular weight aromatics are depleted because of their greater water solubility (Kawka and Simoneit, 1990).

The phenanthrene to methylphenanthrenes (P/MP) ratio and the methylphenanthene indices, MPI 1 and MPI 2, were calculated according to Radke and Welte (1983). The ranges for all samples are $\mathrm{P} / \mathrm{MP}=0.14$ to 1.35 , MPI $1=0.24$ to 1.66 , and MPI $2=0.34$ to 1.91 (Table 3 ). The higher alkyl homologs are present at typically decreasing concentrations, as observed for other hydrothermal petroleums, and the indices are also similar (Kawka and Simoneit, 1990; Kvenvolden and Simoneit, 1990). A dominant peak in the $\mathrm{m} / \mathrm{z} 234$ fragmentograms has a mass spectrum (m/z 101 (10), 189 (20), 190 (10), 191 (10), 202 (25), 203 (28), 204 (30), 217 (10), 219 (100), 220 (18), $234(60), 235$ (11)) that fits for retene or 1,7-dimethyl-8-ethylphenanthrene (XXIII). Retene has a terrestrial source and the latter compound could derive from marine algae (e.g., tasmanites; Simoneit et al., 1990). Coinjection of authentic standards is needed to confirm the compound identity.
The higher molecular weight PAHs are comprised mainly of benzofluoranthenes, benzo(e)pyrene, benzo(a)pyrene, indenopyrene, benzo(ghi)perylene, coronene, and unknowns of molecular weight 326 (Fig. 13). There are seven compounds of molecular weight 326 that have been assigned structures based on emission and excitation spectra in an extract from carbon black (Peadon et al., 1980). Possible structural suggestions for these unknown compounds in the Leg 139 samples are tribenzo[a,cd,jk]pyrene (XXIV), dibenzo[b,pqr]perylene (XXV), naphtho[1,2,3,4-ghi]perylene (XXVI), dibenzo[cd,lm]perylene (XXVII), and naphtho[8,1,2-bcd]perylene (XXVIII), but confirmation would be necessary with authentic standards.

The presence of the analogs with a five-membered alicyclic ring (e.g., benzofluoranthenes, indenopyrene), as well as the other pericondensed aromatic hydrocarbons, confirms the high-temperature origin of these PAHs (Simoneit and Lonsdale, 1982; Blumer, 1975; Scott, 1982; Simoneit, 1984). The only trend observed in the PAH distributions from immature to mature samples (cf. Figs. 13A vs. 13B or $13 \mathrm{C}$ ) is the relative decrease of perylene vs. benzofluoranthenes and 


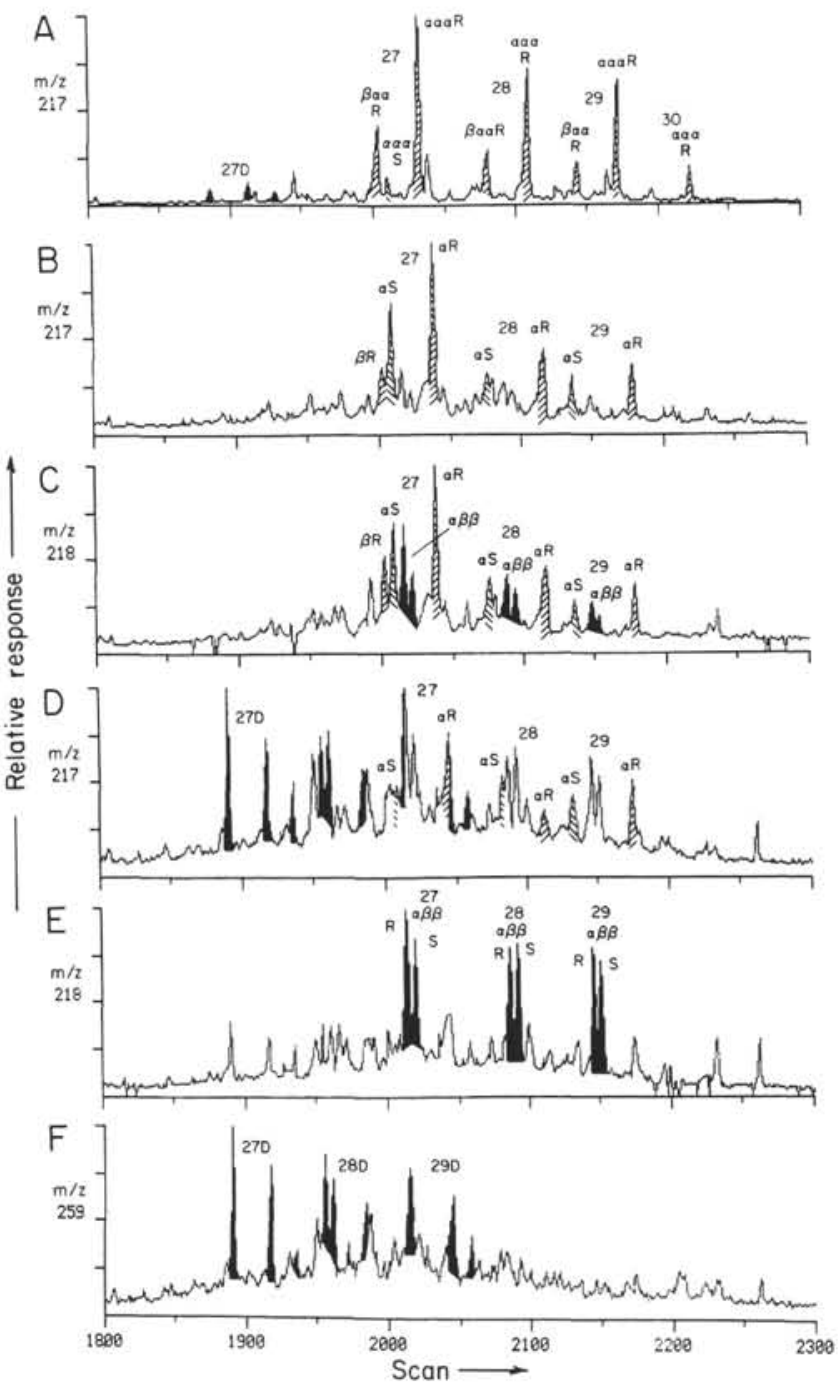

Figure 12. Representative mass fragmentograms (m/z 217, 218, and 259) for the steranes in the bitumen extracts of Leg 139 sediments. A. Sample 139858C-2H-CC (B, m/z 217; and C, m/z 218). Sample 139-858C-3H-1, 44-45 $\mathrm{cm}(\mathbf{D}, \mathrm{m} / \mathrm{z} 217 ; \mathbf{E}, \mathrm{m} / \mathrm{z} 218 ; \mathbf{F}, \mathrm{m} / \mathrm{z} 259)$. Sample 139-858A-1H-1, 149-150 $\mathrm{cm}(\alpha \alpha \alpha$ or $\alpha=5 \alpha(\mathrm{H}), 14 \alpha(\mathrm{H}), 17 \alpha(\mathrm{H})$-steranes, $\beta \alpha \alpha$ or $\beta=5 \beta(\mathrm{H}), 14 \alpha(\mathrm{H})$, $17 \alpha(\mathrm{H})$ configuration, $\alpha \beta \beta=5 \alpha(\mathrm{H}), 14 \beta(\mathrm{H}), 17 \beta(\mathrm{H})$ configuration. $\mathrm{S}$ and $\mathrm{R}$ are diastereomers at $\mathrm{C}-20 . \mathrm{D}=$ diasteranes. Numbers refer to the carbon skeleton.

benzopyrenes (from a ratio of 62 to 0.01 , Table 3 ). This is the same trend as described for the Guaymas Basin sediments and hydrothermal petroleums (Baker and Louda, 1982; Simoneit and Philp, 1982; Simoneit et al., 1984; Kawka and Simoneit, 1990). Perylene is generated by diagenetic processes at depth but is not stable at catagenetic temperatures (Louda and Baker, 1984; Kawka and Simoneit, 1990). Minor amounts of fluoranthene and pyrene are present in highly variable ratios (fluoranthene/pyrene range 0.003 to 0.56 , Table 3 ). Significant concentrations of the benzopyrenes are present in most samples. The ratio of benzo(a)pyrene to benzo(e)pyrene (BaP/BeP, Table 3) has been used to gauge the extent of atmospheric secondary oxidation of the PAH once formed, because $\mathrm{BaP}$ is less stable than BeP (Lane, 1989; Nielsen et al., 1984). At the seafloor these compounds may be reactive to other oxidizing agents, but with similar reactivities. The $\mathrm{BaP} / \mathrm{BeP}$ range for these samples is from $<0.02$ to 1.0 , where a typical precursor value is $>0.4$ and those samples with a ratio $<0.4$ have had an oxidative or thermal loss of $\mathrm{BaP}$. The ratio of coronene to the total benzofluoranthenes plus BeP plus BaP (Table 3)

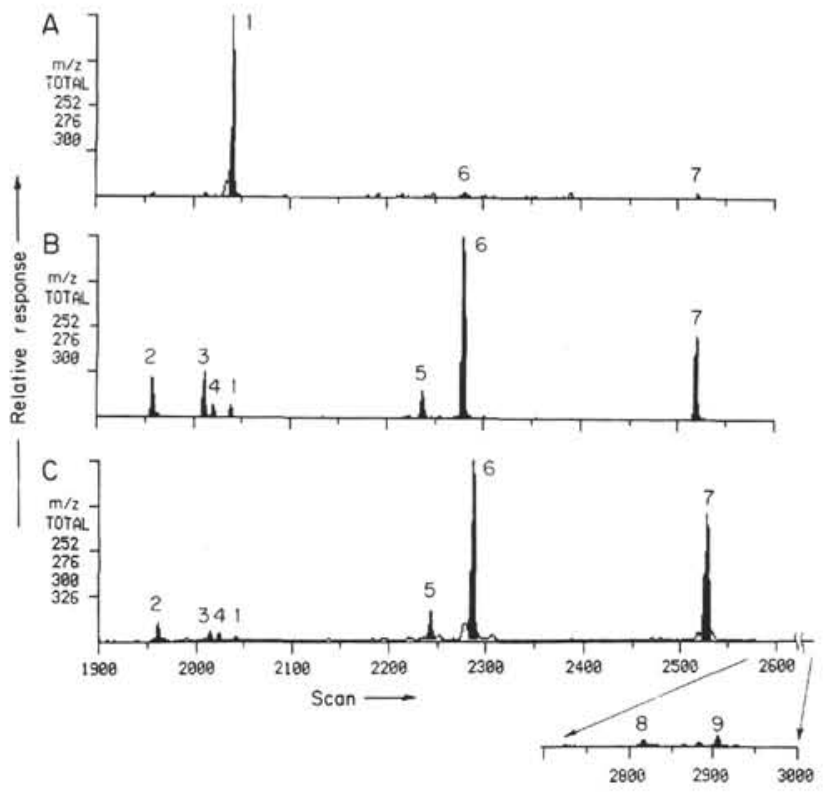

Figure 13. Salient features of the PAH distributions in samples from Leg 139. A. Sample 139-855D-4R-CC. B. Sample 139-858B-1H-2,31-32 cm. C. Sample 139-858B-1H-2, 42-44 cm. (Peak numbers are: $1=$ perylene, $2=$ benzofluoranthene, 3 = benzo(e)pyrene, 4 = benzo(a)pyrene, $5=$ indenopyrene, $6=$ benzo (ghi)perylene, $7=$ coronene, 8 and $9=$ unknowns m.w. 326 .)

reflects the content of PAHs with higher molecular weight and ranges from 0.02 to 6.7 .

\section{Implications}

Although the organic matter content (TOC ranges from $0.0 \%$ to $1.2 \%$; mean values: Site $855,0.47 \%$; Site $856,0.34 \%$; Site 857 , $0.36 \%$; Site $858,0.32 \%$; overall mean $=0.37 \%$; Davis, Mottl, Fisher, et al. [1992]) is low for all sites, maturation and catagenesis occurred because of the hydrothermal activity. Maturation occurs in situ as accelerated diagenesis of the immature organic matter with the biomarker precursors to catagenesis, yielding hydrothermal petroleum at Sites 856 and 857 . Only accelerated diagenesis due to enhanced heat flow is observed in the sediments of Site 855. At Site 858 both hydrothermal petroleum generation and migration are observed, and based on the diverse hydrocarbon signatures, migration occurs more laterally rather than vertically, which results in discrete bitumen intervals.

The source organic matter in Middle Valley sediments is enriched in terrestrial detritus and thus the kerogen is inferred to be depleted in aliphatic moieties, in contrast to the aliphatic-rich marine organic matter in Guaymas Basin. Hydrothermal alteration of this Middle Valley organic matter yields high concentrations of hydrocarbons $>n-C_{15}$, and because of the low TOC content the maturation proceeds to a CPI of $<1.0$ for the n-alkanes (i.e., a strong even-carbon-number predominance). The origin of the excess of the even-carbon-numbered $n$-alkanes from fatty alcohols was inferred but could not be proven with these data. Maturation resulting from elevated temperatures is also evident in the ratios of $\mathrm{Pr} / \mathrm{Ph}, \mathrm{Pr} / n-\mathrm{C}_{17}$, and $\mathrm{Ph} / n-\mathrm{C}_{18}$. The isoprenoid hydrocarbons are lost from the system more rapidly than the $n$-alkanes and/or are overwhelmed by newly generated $n$-alkanes as the temperature rises.

The alteration of biomarkers from the natural product precursors to the geological products occurs according to the respective temperature regimes at all sites. The major precursor compound classes that were used as markers are sterols, terrigenous triterpenoids, and microbial hopanoids. Their major alteration products are saturated hydrocarbons (steranes and triterpanes) derived from reductive processes via various 
Table 3. Presence and maturity parameters of aromatic hydrocarbons in Leg 139 samples.

\begin{tabular}{|c|c|c|c|c|c|c|c|c|c|c|c|}
\hline \multirow[b]{2}{*}{$\begin{array}{l}\text { Core, section, } \\
\text { interval }(\mathrm{cm})\end{array}$} & \multirow[b]{2}{*}{$\begin{array}{l}\text { Depth } \\
\text { (mbsf) }\end{array}$} & \multicolumn{3}{|c|}{ Presence of $\mathrm{PAH}^{\mathrm{a}}$} & \multicolumn{3}{|c|}{ Phenanthrene series ${ }^{b}$} & \multirow[b]{2}{*}{$\begin{array}{l}\text { Fluoranthene/ } \\
\text { pyrene }\end{array}$} & \multirow[b]{2}{*}{$\begin{array}{c}\text { Perylene/ } \\
\text { benzofluoranthene } \\
+\mathrm{BaP}+\mathrm{BeP}\end{array}$} & \multirow[b]{2}{*}{$\mathrm{BaP} / \mathrm{BeP}$} & \multirow[b]{2}{*}{$\begin{array}{l}\text { Coronene/ } \mathrm{BaP}+\mathrm{BeP} \\
+ \text { benzofluoranthene }\end{array}$} \\
\hline & & $\begin{array}{c}\text { Low } \\
\text { molecular } \\
\text { weight }(<228)\end{array}$ & $\begin{array}{l}\text { Intermediate } \\
\text { molecular weight } \\
(<300)\end{array}$ & $\begin{array}{c}\text { High } \\
\text { molecular } \\
\text { weight }(>300)\end{array}$ & $\mathrm{P} / \mathrm{MP}$ & MPI 1 & MPI 2 & & & & \\
\hline $\begin{array}{c}\text { 139-855D- } \\
\text { 4R-CC }\end{array}$ & 108.5 & + & + & - & 0.26 & 1.00 & 1.20 & 0.500 & 62.00 & & 1.90 \\
\hline $\begin{array}{c}\text { 139-856A- } \\
2 \mathrm{H}-\mathrm{CC}\end{array}$ & 12.0 & + & + & - & 0.83 & 0.24 & & 0.560 & 50.00 & & 0.03 \\
\hline $\begin{array}{l}139-857 \mathrm{~A}- \\
1 \mathrm{H}-1,0-1 \\
8 \mathrm{H}-2,95-99\end{array}$ & $\begin{array}{r}1.9 \\
62.0\end{array}$ & $\overline{+}$ & $\begin{array}{l}+ \\
+\end{array}$ & $\overline{-}$ & 0.55 & 0.78 & 0.82 & 0.310 & & $<0.02$ & 0.57 \\
\hline $\begin{array}{l}\text { 139-857C- } \\
6 \mathrm{R}-\mathrm{CC} \\
9 \mathrm{R}-\mathrm{CC} \\
48 \mathrm{R}-1,73-75\end{array}$ & $\begin{array}{r}95.0 \\
124.0 \\
409.0\end{array}$ & $\begin{array}{l}+ \\
+ \\
+\end{array}$ & $\begin{array}{l}+ \\
+ \\
+\end{array}$ & $\bar{z}$ & 0.26 & 0.94 & 0.91 & 0.300 & $\begin{array}{l}11.00 \\
0.10\end{array}$ & $\begin{array}{r}<0.02 \\
0.03\end{array}$ & $\begin{array}{l}0.60 \\
4.90 \\
0.02\end{array}$ \\
\hline $\begin{array}{l}139-858 \mathrm{~A}- \\
1 \mathrm{H}-1,149-150 \\
4 \mathrm{H}-4,52-56 \\
6 \mathrm{H}-\mathrm{CC}\end{array}$ & $\begin{array}{r}1.5 \\
26.5 \\
50.0\end{array}$ & $\begin{array}{l}+ \\
+ \\
+\end{array}$ & $\begin{array}{l}+ \\
+ \\
+\end{array}$ & $\overline{-}$ & $\begin{array}{l}0.47 \\
0.40\end{array}$ & $\begin{array}{l}0.67 \\
1.46\end{array}$ & $\begin{array}{l}0.74 \\
1.63\end{array}$ & $\begin{array}{l}0.140 \\
0.500\end{array}$ & $\begin{array}{l}1.80 \\
0.16 \\
0.15\end{array}$ & $\begin{array}{l}0.20 \\
1.0\end{array}$ & $\begin{array}{l}0.33 \\
0.05 \\
6.70\end{array}$ \\
\hline $\begin{array}{l}139-858 \mathrm{~B}- \\
1 \mathrm{H}-1,48-52 \\
1 \mathrm{H}-2,31-32 \\
1 \mathrm{H}-2,42-44\end{array}$ & $\begin{array}{l}0.5 \\
1.8 \\
1.9\end{array}$ & $\begin{array}{l}+ \\
+ \\
+\end{array}$ & $\begin{array}{l}+ \\
+ \\
+\end{array}$ & $\begin{array}{l}+ \\
+ \\
+\end{array}$ & $\begin{array}{l}0.14 \\
0.47\end{array}$ & $\begin{array}{l}1.66 \\
1.03\end{array}$ & $\begin{array}{l}1.57 \\
0.91\end{array}$ & $\begin{array}{l}0.400 \\
0.250\end{array}$ & $\begin{array}{l}0.06 \\
0.11 \\
0.10\end{array}$ & $\begin{array}{l}0.18 \\
0.28 \\
0.77\end{array}$ & $\begin{array}{l}1.30 \\
0.82 \\
3.30\end{array}$ \\
\hline $\begin{array}{l}139-858 \mathrm{C}- \\
2 \mathrm{H}-5,71-73 \\
2 \mathrm{H}-\mathrm{CC} \\
3 \mathrm{H}-1,44-45 \\
3 \mathrm{H}-2,68-69 \\
3 \mathrm{H}-2,110-115\end{array}$ & $\begin{array}{l}10.2 \\
13.0 \\
13.5 \\
15.0 \\
15.5\end{array}$ & $\begin{array}{l}+ \\
+ \\
+ \\
+\end{array}$ & $\begin{array}{l}+ \\
+ \\
+ \\
+\end{array}$ & $\begin{array}{l}+ \\
+ \\
+ \\
+ \\
+\end{array}$ & 1.35 & 0.79 & 0.91 & $\begin{array}{l}0.170 \\
0.003\end{array}$ & 0.01 & $\begin{array}{r}<0.02 \\
0.13 \\
0.06 \\
0.03 \\
0.12\end{array}$ & $\begin{array}{l}0.60 \\
4.80 \\
1.60 \\
4.20 \\
1.90\end{array}$ \\
\hline $\begin{array}{l}\text { 139-858D- } \\
1 \mathrm{H}-1,0-1 \\
1 \mathrm{H}-1,67-70 \\
1 \mathrm{H}-4,146-150 \\
2 \mathrm{H}-\mathrm{CC}, 37-40 \\
3 \mathrm{P}-1,54-56\end{array}$ & $\begin{array}{r}0.0 \\
0.7 \\
6.0 \\
18.8 \\
19.3\end{array}$ & $\begin{array}{l}+ \\
+ \\
+ \\
+ \\
+\end{array}$ & $\begin{array}{l}+ \\
+ \\
+ \\
+ \\
+\end{array}$ & $\begin{array}{l} \pm \\
\frac{+}{+} \\
+ \\
+\end{array}$ & $\begin{array}{l}0.49 \\
0.71 \\
0.86 \\
0.53 \\
1.17\end{array}$ & $\begin{array}{l}0.89 \\
0.68 \\
0.41 \\
1.45 \\
0.77\end{array}$ & $\begin{array}{l}0.99 \\
0.91 \\
0.34 \\
1.91 \\
1.00\end{array}$ & $\begin{array}{l}0.20 \\
0.36 \\
0.48 \\
0.06 \\
0.08\end{array}$ & $\begin{array}{l}0.31 \\
4.00 \\
5.60\end{array}$ & $\begin{array}{l}0.10 \\
0.50 \\
0.12 \\
0.20 \\
0.23\end{array}$ & $\begin{array}{l}2.20 \\
1.30 \\
0.46 \\
4.80 \\
4.50\end{array}$ \\
\hline
\end{tabular}

${ }^{\mathrm{a}}$ Presence indicated as + , not detectable as -

${ }^{\mathrm{b}} \mathrm{P} / \mathrm{MP}=$ phenanthrene/methylphenanthrenes, MPI $1=\frac{1.5(3 \mathrm{MP}+2 \mathrm{MP})}{\mathrm{P}+9 \mathrm{MP}+1 \mathrm{MP}}\left(\right.$ Radke and Welte, 1983), MPI $2=\frac{3(2 \mathrm{MP})}{\mathrm{P}+9 \mathrm{MP}+1 \mathrm{MP}}($ Radke and Welte, 1983).

oxygenated intermediates (e.g., ketones). The biomarkers consist of a major terrestrial component as reflected by the enrichment of the $\mathrm{C}_{29}$ steroidal compounds and the terrigenous triterpenoids. As the thermal stress increases the biomarkers are cracked to smaller moieties; for example, the $\mathrm{C}_{32}$ and $\mathrm{C}_{35}$ hopanes are converted to $\mathrm{C}_{27}$ and $\mathrm{C}_{29}$ norhopanes. At temperatures in excess of $\sim 280^{\circ}-300^{\circ} \mathrm{C}$ the biomarkers are destroyed.

All samples contain PAHs as is typical for hydrothermal petroleum (Simoneit, 1984; Kawka and Simoneit, 1990; Simoneit et al., 1992). The low molecular weight PAHs and alkyl-PAHs (e.g., alkylnaphthalenes, phenanthrene) are depleted in the deeper sediment sections where the temperature is higher and are found enhanced in shallow immature sediments of all Leg 139 sites. This indicates extensive water/hydrothermal fluid washing of these sections, which removed the lower molecular weight PAHs because of their greater solubility and redistributed them upward, although there is no enriched interval at any depth. The major PAHs are higher molecular weight $(>250$ dalton) components and in contrast to other hydrothermal petroleums (e.g., Escanaba Trough, Kvenvolden and Simoneit, 1990; Guaymas Basin, Simoneit, 1984), there are significant concentrations of unknown PAHs with molecular weights $>300$. These PAHs represent products from the high-temperature alteration of organic matter. The PAH mixture in the Middle Valley sediments is interpreted to derive from fluid contact in excess of $350^{\circ} \mathrm{C}$ and selective concentration by removal of the lower molecular weight constituents.

\section{CONCLUSIONS}

Organic compound maturation is observed at all Leg 139 sites. At locales with high heat flow resulting from hydrothermal activity, the immature organic matter is efficiently converted to hydrothermal petroleum.

The compound signatures in sediments from Sites 855 and 856 reflect in situ accelerated diagenesis of the biological precursors without product migration. The biomarker tracers indicate an enrichment of terrestrial components, with a significant amount of biomarkers derived from marine autochthonous sources. Fluid migrations through these sediments have added minor amounts of dissolved organic compounds derived from higher temperature alteration (e.g., low-molecular-weight aromatic hydrocarbons) to the in-situ components, resulting in mixtures of bitumen with various maturities.

The organic matter in sediments at Site 857 has also experienced in-situ accelerated diagenesis and catagenesis, yielding fully mature bitumen at depth. One interval appears to contain a minor amount of migrated bitumen, based on elevated yield (Hole $857 \mathrm{C}, 82 \mathrm{mbsf}$ ). The biomarkers indicate a significant input of terrestrial components with the predominant material derived from marine autochthonous sources. Maturation has proceeded to yield n-alkanes with a strong evencarbon-number predominance, where the CPI varies from $>1.0$ in immature sections, to one, and then $<1.0$ in the fully mature sections. Due to the low TOC these sediments do not generate high amounts of hydrocarbons from kerogen, as is the case in Guaymas Basin, thus revealing the unique even-to-odd preference of the $n$-alkanes in the mature samples.

The sedimentary organic matter at Site 858 has been converted to hydrothermal petroleum. Relatively immature bitumen is encountered only in the upper few meters of the holes. The biomarkers in the upper sections show a moderate input of terrestrial components, with products derived predominantly from autochthonous marine sources. Maturation has progressed to form $n$-alkanes with a strong even- 
carbon-number predominance $(\mathrm{CPI}<1.0)$ at depth in Holes $858 \mathrm{~A}$, $858 \mathrm{~B}, 858 \mathrm{C}$, and $858 \mathrm{D}$. There is an overmature bitumen interval in Hole $858 \mathrm{~A}$ at about $50 \mathrm{mbsf}$. The different hydrothermal petroleum intervals (zones with high bitumen concentrations) have many compositions (condensates to asphalts) and maturities, reflecting formation in various temperature windows followed by lateral migration into the sediment sections sampled.

The biomarkers are present as precursors, intermediates, and fully mature products. The sterols are altered to stenones, stanones, and then steranes; the terrigenous triterpenols proceed to triterpenones, triterpenes, and then triterpanes; and the bacterial hopenes and hopanols are converted to hopanes. Maturation of the biomarkers begins here with the biogenic precursors and results in their interconversion to the thermodynamically most stable configurations as known in conventional sedimentary basins with mature organic matter. Cracking reactions degrade higher molecular weight compounds to smaller molecules (e.g., waxy oil to condensate, $C_{35}$ hopanes to the $C_{29}$ and $C_{27}$ nor compounds).

The high-temperature components in these bitumens are PAHs, as is the case for most hydrothermal petroleums studied to date. These samples contain only traces of low molecular weight PAHs and alkyl PAHs (e.g., phenanthrene/alkylphenanthrenes) and high concentrations of heavy PAHs. This is interpreted to result from the high solubility of the smaller PAHs in warm water and consequent removal from the sediments by pore-fluid flow. Such a process would then concentrate the high molecular weight PAHs in these sediment associated bitumens.

\section{ACKNOWLEDGMENTS}

I thank Dr. R.N. Leif for GC-MS data acquisition and useful comments on this manuscript. I also thank Drs. P.A. Meyers and F.G. Prahl and an anonymous reviewer for their useful comments, especially the latter for the detailed, careful, and critical annotations and suggestions, which greatly improved this paper. Financial support from the National Science Foundation, Division of Ocean Sciences (Grant OCE-9002366) and from the NSF and JOI, Inc., U.S. Science Support Program of the Ocean Drilling Program is gratefully acknowledged.

The U.S. Science Program associated with the Ocean Drilling Program is sponsored by the National Science Foundation and the Joint Oceanographic Institutions, Inc. Any opinions, findings and conclusions or recommendations expressed in this publication are those of the author and do not necessarily reflect the views of the National Science Foundation, the Joint Oceanographic Institutions, Inc., or Texas A\&M University.

\section{REFERENCES}

Albaiges, J., and Torradas, J.M., 1974. Significance of even-carbon $n$-paraffin preference in a Spanish crude oil. Nature, 250:567-568.

Baker, E.W., and Louda, J.W., 1982. Geochemistry of tetrapyrrole, tetraterpenoid, and perylene pigments in sediments from the Gulf of California: Deep Sea Drilling Project Leg 64, Sites 474, 477, 479, and 481, and Scripps Institution of Oceanography Guaymas Basin Survey Cruise Leg 3, Sites 10G and 18G. In Curray, J.R., Moore, D.G., et al., Init. Repts. DSDP, 64 (Pt. 2): Washington (U.S. Govt. Printing Office), 789-814.

Barrett, T.J., and Jambor, J.L. (Eds.), 1988. Seafloor hydrothermal mineralization. Can. Mineral., 26:429-888.

Bazylinski, D.A., Farrington, J.W., and Jannasch, H.W., 1988. Hydrocarbons in surface sediments from a Guaymas Basin hydrothermal vent site. Org. Geochem., 12:547-558.

Blumer, M., 1975. Curtisite, idrialite and pendletonite, polycyclic aromatic hydrocarbon minerals: their composition and origin. Chem. Geol., 16:245-256.

\footnotetext{
- Abbreviations for names of organizations and publications in ODP reference lists follow the style given in Chemical Abstracts Service Source Index (published by American Chemical Society).
}

Brassell, S.C., Eglinton, G., and Maxwell, J.R., 1983. The geochemistry of terpenoids and steroids. Biochem. Soc. Trans., 11:575-586.

Brault, M., and Simoneit, B.R.T., 1988. Steroid and triterpenoid distributions in Bransfield Strait sediments: hydrothermally-enhanced diagenetic transformations. In Mattavelli, L., and Novelli, L. (Eds.), Advances in Organic Geochemistry 1987, Org. Geochem., 13:697-705.

Brault, M., Simoneit, B.R.T., and Saliot, A., 1989. Trace petroliferous organic matter associated with massive hydrothermal sulfides from the East Pacific Rise at $13^{\circ} \mathrm{N}$ and $21^{\circ} \mathrm{N}$. Oceanol. Acta, 12:405-415.

Corbet, B., Albrecht P., and Ourisson G., 1980. Photochemical or photomimetic fossil triterpenoids in sediments and petroleums. J. Am. Chem. Soc., 102:1171-1173.

Curray, J.R., Moore, D.G., et al., 1982. Init. Repts. DSDP, 64 (Pts. 1 and 2): Washington (U.S. Govt. Printing Office).

Dastillung, M., 1976. Lipides de sediments recents [Ph.D. thesis]. Univ. Louis Pasteur, Strasbourg, France.

Davis, E.E., Goodfellow, W.D., Bornhold, B.D., Adshead, J., Blaise, B., Villinger, H., and Le Cheminant, G.M., 1987. Massive sulfides in a sedimented rift valley, northern Juan de Fuca Ridge. Earth Planet. Sci. Lett., 82:49-61.

Davis, E.E., Mottl, M.J., Fisher, A.T., et al., 1992. Proc. ODP, Init. Repts., 139: College Station, TX (Ocean Drilling Program).

Davis, E.E., Mottl, M., Fisher, A., Baker, P.A., Becker, K., Boni, M., Boulègue, J.J., Brunner, C.A., Duckworth, R.C., Franklin, J.M., Goodfellow, W.D., Gröschel-Becker, H.M., Kinoshita, M., Konyukhov, B.A., Körner, U., Krasnov, S.G., Langseth, M., Mao, S., Marchig, V., Marumo, K., Oda, H., Rigsby, C.A., Simoneit, B.R.T., Stakes, D.S., Villinger, H.W., Wheat, C.G., Whelan, J., and Zierenberg, R.A., 1992. Hot rocks and massive sulfide: northern Juan de Fuca Ridge. Eos, 73:193, 196-198.

Davis, E.E., and Villinger, H., 1992. Tectonic and thermal structure of the Middle Valley sedimented rift, northern Juan de Fuca Ridge. In Davis, E.E., Mottl, M.J., Fisher, A.T., et al., Proc. ODP, Init. Repts., 139: College Station, TX (Ocean Drilling Program), 9-41.

Dembicki, H., Jr., Meinschein, W.G., and Hatten, D.E., 1976. Possible ecological and environmental significance of the predominance of even-carbon number $\mathrm{C}_{20}-\mathrm{C}_{30}$ n-alkanes. Geochim. Cosmochim. Acta, 40:203-208.

Didyk, B.M., and Simoneit, B.R.T., 1989. Hydrothermal oil of Guaymas Basin and implications for petroleum formation mechanisms. Nature, 342:65-69. 1990. Petroleum characteristics of the oil in a Guaymas Basin hydrothermal chimney. In Simoneit, B.R.T., Organic Matter in Hydrothermal Systems-Petroleum Generation, Migration and Biogeochemistry. Appl. Geochem., 5:29-40.

Didyk, B.M., Simoneit, B.R.T., Brassell, S.C., and Eglinton, G., 1978. Organic geochemical indicators of palaeoenvironmental conditions of sedimentation. Nature, 272:216-222.

Ekweozor, C.M., and Udo, O.T., 1988. The oleananes: origin, maturation and limits of occurrence in southern Nigeria sedimentary basins. In Mattavelli, L., and Novelli, L., (Eds.), Advances in Organic Geochemistry 1987. Org. Geochem., 13:131-140.

Ensminger, A., Albrecht, P., Ourisson, G., and Tissot, B., 1977. Evolution of polycyclic alkanes under the effect of burial (Early Toarcian Shales, Paris Basin). In Campos, R., and Goni, J. (Eds.), Advances in Organic Geochemistry 1975: Madrid (ENADIMSA), 45-52.

Ensminger, A., van Dorsselaer, A., Spyckerelle, C., Albrecht, P., and Ourisson, G., 1974. Pentacyclic triterpenes of the hopane type as ubiquitous geochemical markers: origin and significance. In Tissot, B., and Bienner, F. (Eds.), Advances in Organic Geochemistry 1973: Paris (Editions Technip), 245-260.

Farrington, J.W., Davis, A.C., Tarafa, M.E., McCaffery, M.A., Whelan, J.K., and Hunt, J.M., 1988. Bitumen molecular maturity parameters in the Ikpikpuk well, Alaskan North Slope. Org. Geochem., 13:303-310.

Gieskes, J.M., Simoneit, B.R.T., Brown, T., Shaw, T., Wang, Y.-C., and Magenheim, A., 1988. Hydrothermal fluids and petroleum in surface sediments of Guaymas Basin, Gulf of California: a case study. Can. Mineral., 26:589-602.

Goutx, M., and Saliot, A., 1980. Relationship between dissolved and particulate fatty acids and hydrocarbons, chlorophyll a and zooplankton biomass in Villefranche Bay, Mediterranean Sea. Mar. Chem., 8:299-318.

Grimalt, J., and Albaiges, J., 1987. Sources and occurrence of $\mathrm{C}_{12}-\mathrm{C}_{22} n$-alkane distributions with even carbon-number preference in sedimentary environments. Geochim. Cosmochim. Acta, 51:1379-1384.

Grimalt, J., Albaiges, J., Alexander, G., and Hazai, I., 1986. Predominance of even carbon-numbered $n$-alkanes in coal seam samples of Nograd basin (Hungary). Naturwissenschaften, 73:729-731. 
Hauke, V., Graff, R., Wehrung, P., Trendel, J.M., Albrecht, P., Schwark, L., Keely, B.J., and Peakman, T.M., 1992. Novel terpene-derived hydrocarbons of arborane/fernane series in sediments. Tetrahedron, 48:3915-3924.

Hunt, J.M., 1979. Petroleum Geochemistry and Geology: San Francisco (W.H. Freeman).

Kawka, O.E., and Simoneit, B.R.T., 1987. Survey of hydrothermally-generated petroleums from the Guaymas Basin spreading center. Org. Geochem., 11:311-328.

, B.R.T., 1990. Polycyclic aromatic hydrocarbons in hydrothermal petroleums from the Guaymas Basin spreading center. In Simoneit, B.R.T. (Ed.), Organic Matter in Hydrothermal Systems-Petroleum Generation, Migration and Biogeochemistry. Appl. Geochem., 5:17-27.

Kennicutt, M.C., II, and Brooks, J.M., 1990. Unusual normal alkane distributions in offshore New Zealand sediments. Org. Geochem., 15:193-197.

Kvenvolden, K.A., Rapp, J.B., Hostettler, F.D., Morton, J.L., King, J.D., and Claypool, G.E., 1986. Petroleum associated with polymetallic sulfide in sediment from the Gorda Ridge. Science, 243:1231-1234.

Kvenvolden, K.A., and Simoneit, B.R.T., 1990. Hydrothermally derived petroleum: examples from Guaymas Basin, Gulf of California and Escanaba Trough, Northeast Pacific Ocean. AAPG Bull., 74:223-237.

Lane, D.A., 1989. The fate of polycyclic aromatic compounds in the atmosphere and during sampling. In Vo-Dinh, T. (Ed.), Chemical Analysis of Polycyclic Aromatic Compounds. Chem. Anal., 101:31-58.

Leif, R.N., 1993. Laboratory simulated hydrothermal alteration of sedimentary organic matter from Guaymas Basin, Gulf of California [Ph.D. thesis] Oregon State Univ., Corvallis.

Leif, R.N., Simoneit, B.R.T., and Kvenvolden, K.A., 1991. Simulation of hydrothermal petroleum generation by laboratory hydrous pyrolysis. In Manning, D.A.C. (Ed.), Organic Geochemistry: Advances and Applications in the Natural Environment: Manchester (Manchester Univ. Press), 300-303.

, 1992. Hydrous pyrolysis of $n-\mathrm{C}_{32} \mathrm{H}_{66}$ in the presence and absence of inorganic components. Am. Chem. Soc., Div. Fuel Chem., 204th Nat. Meet., Preprints, 37:1748-1753.

Lewan, M.D., 1987. Petrographic study of primary petroleum migration in the Woodford Shale and related rock units. In Doligez, B. (Ed.)., Migration of Hydrocarbons in Sedimentary Basins: Paris (Editions Technip), 113-130.

Louda, J.W., and Baker, E.W., 1984. Perylene occurrence and possible sources in deep-ocean sediments. Geochim. Cosmochim. Acta, 48:1043-1058.

Mackenzie, A.S., Brassell, S.C., Eglinton, G., and Maxwell, J.R., 1982. Chemical fossils: the geological fate of steroids. Science, 217:491-504.

Mackenzie, A.S.,Patience, R.L., Maxwell, J.R., Vandenbroucke, M., and Durand, B., 1980. Molecular parameters of maturation in the Toarcian shales, Paris Basin, France- - I. Changes in the configurations of acyclic isoprenoid alkanes, steranes and triterpanes. Geochim. Cosmochim. Acta, 44:1709-1721.

Nielsen, T., Seitz, B., and Ramdahl, T., 1984. Occurrence of nitro-PAH in the atmosphere in a rural area. Atmos. Environ., 18:2159-2165.

Nishimura, M., and Baker, E.W., 1986. Possible origin of $n$-alkanes with a remarkable even-to-odd predominance in recent marine sediments. Geochim. Cosmochim. Acta, 50:299-305.

Palacas, J.G., Love, A.H., and Gerrild, P.M., 1972. Hydrocarbons in estuarine sediments of Choctawhatchee Bay, Florida, and their implications for genesis of petroleum. AAPG Bull., 56:1402-1418.

Peadon, P.A., Lee, M.L., Hirata, Y., and Novotny, M., 1980. High-performance liquid chromatographic separation of high-molecular-weight polycyclic aromatic compounds in carbon black. Anal. Chem., 52:2268-2271.

Pelet, R., and Debyser, Y., 1977. Organic geochemistry of Black Sea cores. Geochim. Cosmochim. Acta, 41:1575-1586.

Prahl, F.G., and Pinto, L.A., 1987. A geochemical study of long-chain $n$-aldehydes in Washington coastal sediments. Geochim. Cosmochim. Acta, 51:1573-1582.

Radke, M., and Welte, D.H., 1983. The Methylphenanthrene Index (MPI): a maturity parameter based on aromatic hydrocarbons. In Bjorøy, M., et al. (Eds.), Advances in Organic Geochemistry 1981: Chichester (Wiley), 504-512.

Rona, P.A., 1988. Hydrothermal mineralization at oceanic ridges. Can. Mineral., 26:431-465.

Rona, P.A., Boström, K., Laubier, L., and Smith, K.L., Jr. (Eds.), 1983. Hydrothermal Processes at Seafloor Spreading Centers: New York (Plenum).

Saliot, A., and Tissier, M.J., 1978. Inventaire et dynamique des lipides à l'interface eau de mer/sediments. IV. In Combaz, A., and Pelet, R., Geochimie Organique des Sediments Marins Profonds. Mission Orgon II. Atlantique -NE Bresil: Paris (Editions du CNRS), 263-273.
Scott, L.T., 1982. Thermal rearrangements of aromatic compounds. Acc. Chem. Res., 15:52-58.

Seifert, W.K., 1978. Steranes and terpanes in kerogen pyrolysis for correlation of oils and source rocks. Geochim. Cosmochim. Acta, 42:473-484.

Seifert, W.K., and Moldowan, J.M., 1978. Applications of steranes, terpanes and monoaromatics to the maturation, migration and source of crude oils. Geochim. Cosmochim. Acta, 42:77-95.

Seifert, W.K., and Moldowan, J.M., 1979. The effect of biodegradation on steranes and terpanes in crude oils. Geochim. Cosmochim. Acta, 43:111-126.

Sever, J.R., and Haug, P., 1971. Fatty acids and hydrocarbons in Surtsey sediment. Nature, 234:447-450.

Simoneit, B.R.T., 1975. Sources of organic matter in oceanic sediments [Ph.D. thesis]. Univ. of Bristol, England.

, 1977. Diterpenoid compounds and other lipids in deep-sea sediments and their geochemical significance. Geochim. Cosmochim. Acta, 41:463-476.

1978. The organic chemistry of marine sediments. In Riley, J.P. and Chester, R. (Eds.), Chemical Oceanography (2nd ed.)(Vol. 7): New York (Academic Press), 233-311.

_ 1984. Hydrothermal effects on organic matter-high versus low temperature components. In Schenck, P.A., deLeeuw, J.W., and Lijmbach, G.W.M. (Eds.), Advances in Organic Geochemistry 1983: Oxford (Pergamon Press), 857-864.

, 1985. Hydrothermal petroleum: Genesis, migration and deposition in Guaymas Basin, Gulf of California. Can. J. Earth Sci., 22:1919-1929.

-, 1986. Cyclic terpenoids of the geosphere. In Johns, R.B. (Ed.), Biological Markers in the Sedimentary Record: Internat. Geol. Correlation Proj. 157, Amsterdam (Elsevier), 43-99.

(Ed.), 1990a. Organic matter in hydrothermal systems-maturation, migration and biogeochemistry. Appl. Geochem., 5:1-248.

$-1990 \mathrm{~b}$. Petroleum generation-an easy and widespread process in hydrothermal systems: an overview. In Simoneit, B.R.T. (Ed.), Organic Matter in Hydrothermal Systems-Petroleum Generation, Migration and Biogeochemistry. Appl. Geochem., 5:3-15.

, 1992a. Aqueous organic geochemistry at high temperature/high pressure. Origins Life Evol. Biosphere, 22:43-45.

1992b. Natural hydrous pyrolysis-Petroleum generation in submarine hydrothermal systems. In Whelan, J.K., and Farrington, J.W. (Eds.), Productivity, Accumulation and Preservation of Organic Matter in Recent and Ancient Sediments: New York (Columbia Univ. Press), 368-402.

1993. Hydrothermal activity and its effects on sedimentary organic matter. In Parnell, J., et al. (Eds.), Bitumens in Ore Deposits: Berlin (Springer Verlag), 81-95.

Simoneit, B.R.T., Brenner, S., Peters, K.E., and Kaplan, I.R., 1981. Thermal alteration of Cretaceous black shale by basaltic intrusions in the eastern Atlantic. II: Effects on bitumen and kerogen. Geochim. Cosmochim. Acta, 45:1581-1602.

Simoneit, B.R.T., Crisp, P.T., Rohrback, B.G., and Didyk, B.M., 1980. Chilean paraffin dirt-II. Natural gas seepage at an active site and its geochemical consequences. In Douglas, A.G., and Maxwell, J.R., Advances in Organic Geochemistry 1979: Oxford (Pergamon Press), 171-176.

Simoneit, B.R.T., Goodfellow, W.D., and Franklin, J.M., 1992. Hydrothermal petroleum at the seafloor and organic matter alteration in sediments of Middle Valley, northern Juan de Fuca Ridge. Appl. Geochem., 7:257-264.

Simoneit, B.R.T., Leif, R.N., Radler de Aquino Neto, F., Almeida Azevedo, D. Pinto, A.C., and Albrecht, P., 1990. On the presence of tricyclic terpane hydrocarbons in Permian tasmanite algae. Naturwissenschaften, 77:380-383.

Simoneit, B.R.T., Leif, R.N., Sturz, A.A., Sturdivant, A.E., and Gieskes, J.M., 1992. Geochemistry of shallow sediments in Guaymas Basin, Gulf of California: hydrothermal gas and oil migration and effects of mineralogy. Org. Geochem., 18:765-784.

Simoneit, B.R.T., and Lonsdale, P.F., 1982. Hydrothermal petroleum in mineralized mounds at the seabed of Guaymas Basin. Nature, 295:198-202.

Simoneit, B.R.T., Mazurek, M.A., Brenner, S., Crisp, P.T., and Kaplan, I.R., 1979. Organic geochemistry of Recent sediments from Guaymas Basin, Gulf of California. Deep-Sea Res. Part A, 26A:879-891.

Simoneit, B.R.T., and Philp, R.P., 1982. Organic geochemistry of lipids and kerogen and the effects of basalt intrusions on unconsolidated oceanic sediments: Sites 477, 478, and 481, Guaymas Basin, Gulf of California. In Curray, J.R., Moore, D.G., et al., Init. Repts. DSDP, 64 (Pt. 2): Washington (U.S. Govt. Printing Office), 883-904. 
Simoneit, B.R.T., Philp, R.P., Jenden, P.D., and Galimov, E.M., 1984. Organic geochemistry of Deep Sea Drilling Project sediments from the Gulf of California-hydrothermal effects on unconsolidated diatom ooze. Org. Geochem., 7:173-205.

Tissot, B.P., and Welte, D.H., 1984. Petroleum Formation and Occurrence (2nd ed.): Heidelberg (Springer-Verlag).

Volkman, J.K., 1986. A review of sterol markers for marine and terrigenous organic matter. Org. Geochem., 9:83-99.

Von Damm, K.L., 1990. Seafloor hydrothermal activity: black smoker chemistry and chimneys. Annu. Rev. Earth Planet. Sci., 18:173-204.

Welhan, J.A., and Lupton, J.E., 1987. Light hydrocarbon gases in Guaymas Basin hydrothermal fluids: thermogenic versus abiogenic origin. $A A P G$ Bull., 71:215-223.

Welte, D.H., and Ebhardt, G., 1968. Distribution of long chain n-paraffins and n-fatty acids in sediments from the Persian Gulf. Geochim. Cosmochim. Acta, 32:465-466.

Welte, D.H., and Waples, D.W., 1973. Über die Bevorzugung geradzahliger n-Alkane in Sedimentgesteinen. Naturwissenschaften, 60:516-517.

Whelan, J.K., Simoneit, B.R.T., and Tarafa, M., 1988. $C_{1}-C_{8}$ hydrocarbons in sediments from Guaymas Basin, Gulf of California-comparison to Peru Margin, Japan Trench and California Borderlands. Org. Geochem., 12:171-194.

Date of receipt: 4 January 1993

Date of acceptance: 7 September 1993

Ms 139SR-237

\section{GLOSSARY}

Bitumen. In the widest sense, any natural hydrocarbon ranging in state from rigid or highly viscous (asphalt), through the less viscous (tarry) to liquid (petroleum) varieties.

Catagenesis. Thermal alteration of organic material in sediments by increasing temperature. Catagenesis in conventional basins covers the temperature range between diagenesis and rock metamorphism, approximately $50^{\circ}-200^{\circ} \mathrm{C}$. Catagenesis occurs in hydrothermal systems in a higher temperature window $\left(100^{\circ}-400^{\circ} \mathrm{C}\right)$ over brief geological times and overlaps with diagenesis.

Diagenesis. Biological, physical, and chemical alteration of the organic debris in sediments without a pronounced effect from rising temperature. Diagenesis is accelerated due to the higher than normal heat flow in hydrothermal regions and the surrounding sediments, altering lipids and other immature organic detritus to geologically more mature products. The process can in such cases overlap with catagenesis.

Hydrothermal petroleum (bitumen). Product from organic matter alteration by contact with hydrothermal fluids. It consists of compounds generated over a greater temperature window $\left(100^{\circ}-400^{\circ} \mathrm{C}\right)$ than observed for conventional petroleums and can proceed from the biological precursors that have not undergone diagenesis. Fluid extraction and migration of hydrothermal petroleum from the source sediment is highly efficient.

Kerogen. Disseminated organic matter in sedimentary rocks which is insoluble in nonoxidizing acids, bases, and organic solvents. The organic matter initially deposited with unconsolidated sediments is not kerogen but a precursor that is converted to kerogen during diagenesis.

Lipids. A broad term that includes all oil-soluble, water-insoluble organic substances such as fats, waxes, fatty acids, sterols, pigments, and terpenoids. 


\section{APPENDIX}

Chemical Structures Cited
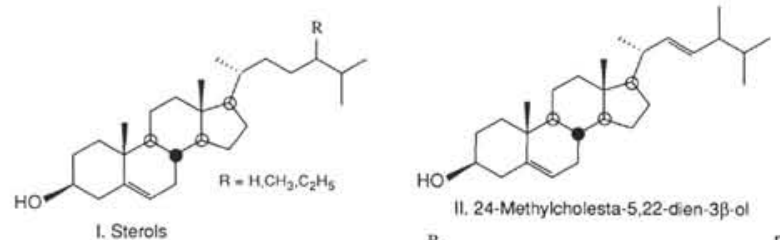

II. 24-Methylcholesta-5,22-dien-33-ol
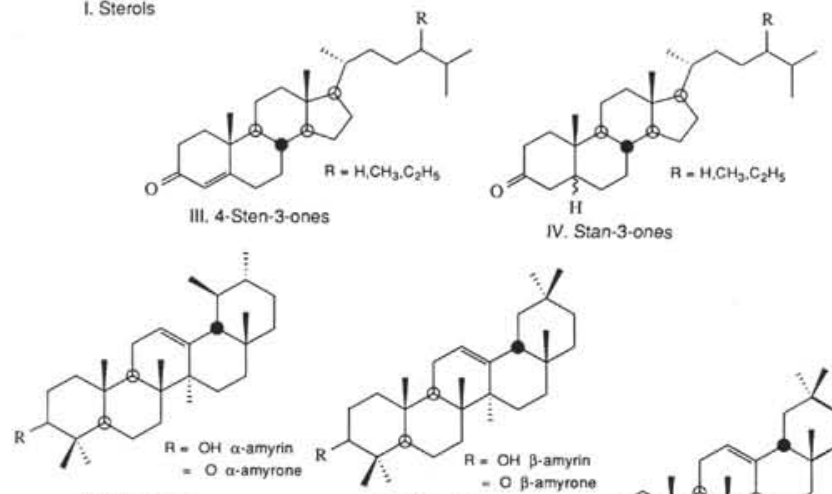

V. Ursenoids

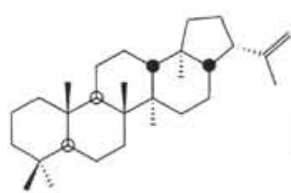

VIII. Diploptene

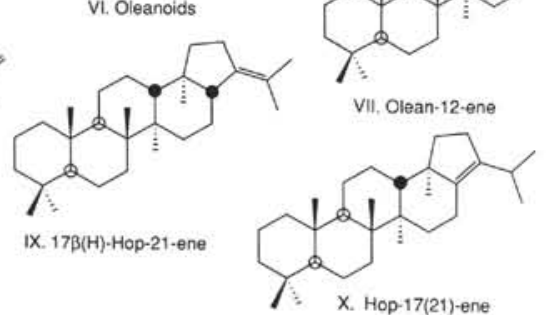

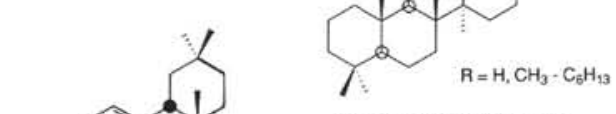

XVI, $17 \alpha(H), 21 \beta(H) \cdot$ Hopanes

XIX. Gammacerane
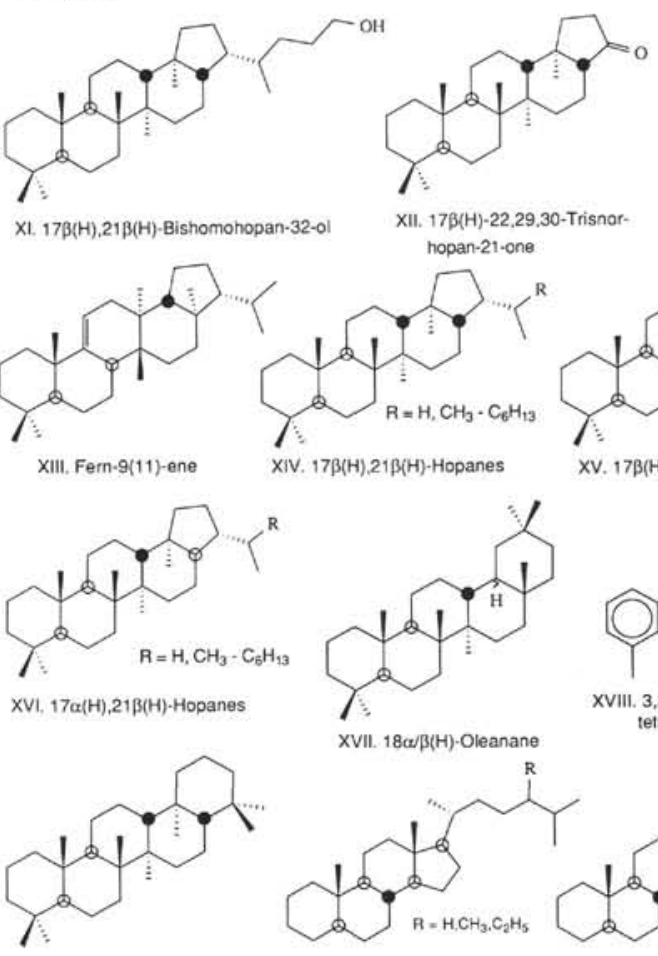

XII. $17 \beta(H)-22,29,30-$ Trisnor-

XI. $17 \beta(H), 21 \beta(H)$-Bishomohopan-32-ol hopan-21-one

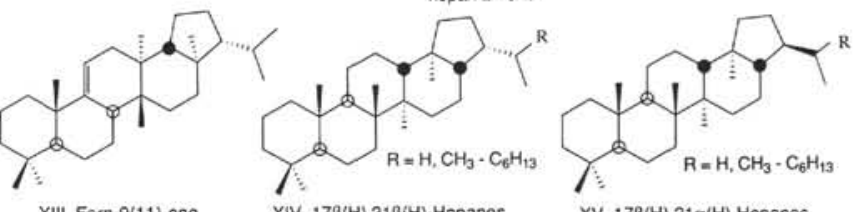

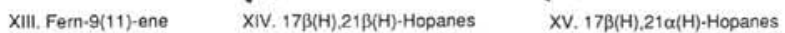
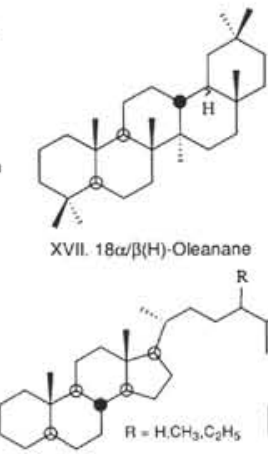

XX. $5 \alpha(\mathrm{H}), 14 \alpha(\mathrm{H}), 17 \alpha(\mathrm{H})$ Steranes

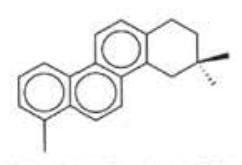

XVIII. 3,3,7-Trimethyl-1,2,3,4

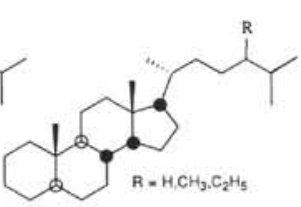

XXL. $5 \alpha(H), 14 \beta(H), 17 \beta(H)$. Steranes

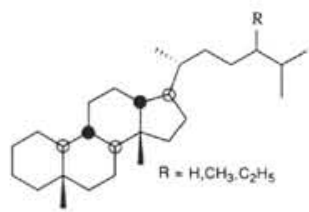

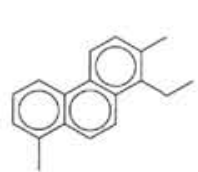

XXIII. 1.7-Dimethyl-8-ethylphenanthrene

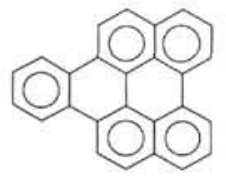

XXVI. Naphtho[1,2,3,4-ghi] perylene

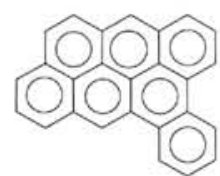

XXIV. Tribenzo[a,cd.jk]pyrene

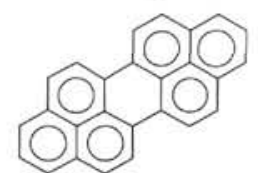

XXVII. Dibenzo[cd,Im]perylene

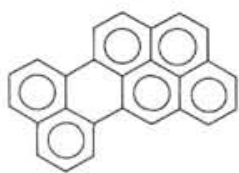

XXVIII. Naphtho[8,1,2-bcod]. perylene 